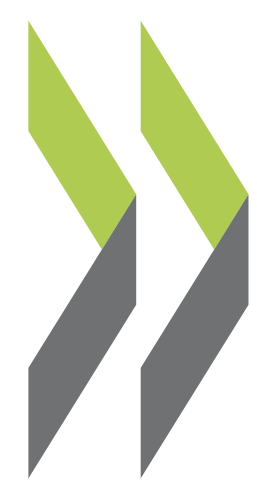

OECD Economics Department Working Papers No. 1116

\title{
Spillover Effects from \\ Exiting Highly Expansionary Monetary Policies
}

\section{Łukasz Rawdanowicz, \\ Romain Bouis, \\ Jérôme Brezillon,}

Ane Kathrine Christensen,

Kei-Ichiro Inaba 
Organisation de Coopération et de Développement Économiques

Organisation for Economic Co-operation and Development

19-May-2014

ECONOMICS DEPARTMENT

English - Or. English

\section{SPILLOVER EFFECTS FROM EXITING HIGHLY EXPANSIONARY MONETARY POLICIES}

ECONOMICS DEPARTMENT WORKING PAPERS No. 1116

By Lukasz Rawdanowicz, Romain Bouis, Jérôme Brezillon, Ane Kathrine Christensen and Kei-Ichiro Inaba

OECD Working Papers should not be reported as representing the official views of the OECD or of its member countries. The opinions expressed and arguments employed are those of the author(s).

Authorised for publication by Jean-Luc Schneider, Deputy Director, Policy Studies Branch, Economics Department.

All OECD Economics Department Working Papers are available through OECD's Internet website at: www.oecd.org/eco/workingpapers

JT03357546

Complete document available on OLIS in its original format

This document and any map included herein are without prejudice to the status of or sovereignty over any territory, to the delimitation of international frontiers and boundaries and to the name of any territory, city or area. 
OECD Working Papers should not be reported as representing the official views of the OECD or of its member countries. The opinions expressed and arguments employed are those of the author(s).

Working Papers describe preliminary results or research in progress by the author(s) and are published to stimulate discussion on a broad range of issues on which the OECD works.

Comments on Working Papers are welcomed, and may be sent to the Economics Department, OECD, 2 rue André-Pascal, 75775 Paris Cedex 16, France, or by e-mail to eco.contact@oecd.org.

This document and any map included herein are without prejudice to the status of or sovereignty over any territory, to the delimitation of international frontiers and boundaries and to the name of any territory, city or area.

The statistical data for Israel are supplied by and under the responsibility of the relevant Israeli authorities. The use of such data by the OECD is without prejudice to the status of the Golan Heights, East Jerusalem and Israeli settlements in the West Bank under the terms of international law.

\section{(c) OECD (2014)}

You can copy, download or print OECD content for your own use, and you can include excerpts from OECD publications, databases and multimedia products in your own documents, presentations, blogs, websites and teaching materials, provided that suitable acknowledgment of OECD as source and copyright owner is given. All requests for commercial use and translation rights should be submitted to rights@oecd.org 
ECO/WKP(2014) 12

\section{ABSTRACT/RÉSUMÉ}

\section{Spillover Effects from Exiting Highly Expansionary Monetary Policies}

The prospective normalisation of monetary policies in the main OECD areas will be challenging given that current policy rates are likely to be significantly below neutral levels and that central bank balance sheets will be above the pre-crisis levels by a wide margin. Monetary policy normalisation is likely to start in the United States before other main OECD areas, with potential global spillovers, as was already experienced in mid-2013 when the mere discussion of tapering unsettled global financial markets. A gradual increase in interest rates, in the context of strong growth and rising equity values, would contribute to a balanced US recovery and have a benign impact on the rest of the world. However, a rapid rise in bond yields would risk generating instability in the US shadow banking sector, and the financial system more generally, even if banks seem increasingly resilient to such a shock. Although model simulations suggest that a large and protracted government bond yield shock would not have large trade spillovers in the absence of crisis events in the United States or abroad, an induced increase in bond yields in other countries, together with an induced large decline in equity prices, would have a sizeable effect on the OECD and largest emerging market economies. The latter countries are particularly vulnerable to such spillovers given their generally less liquid financial markets and, in some cases, weak fundamentals related to the banking system and external financing. In the United States, the authorities should aim at managing smoothly the exit and at strengthening the resilience of shadow banking institutions so that the risk of liquidity-induced fire sales is reduced. This should be accompanied in other countries by measures to increase the resilience to interest rate shocks, and when the shock occurs, allowing exchange rates to adjust flexibly and implementing offsetting fiscal measures if scope is available.

JEL classification codes: E44; E5; F4; G01; G15.

Keywords: monetary policy, spillovers, financial markets, financial crisis.

\section{Les retombées de la sortie des politiques monétaires hautement expansionnistes}

La normalisation à venir des politiques monétaires dans les principales régions de l'OCDE sera difficile étant donné que les taux actuels de politique monétaire sont probablement significativement en deçà des niveaux neutres et que les bilans des banques centrales demeureront largement supérieurs aux niveaux d'avant la crise. La normalisation de la politique monétaire va probablement commencer aux États-Unis avant les autres régions de l'OCDE, avec de possibles retombées mondiales, comme il a déjà été observé à la mi-2013 lorsque la simple évocation de la réduction progressive des politiques accommodantes a déstabilisé les marchés financiers mondiaux. Une hausse graduelle des taux d'intérêt, dans un contexte de croissance soutenue et de valorisations boursières à la hausse, contribuerait à une reprise équilibrée aux États-Unis et aurait un effet bénin sur le reste du monde. Toutefois, une remontée rapide des rendements obligataires pourrait générer une instabilité dans le secteur bancaire parallèle aux États-Unis, et plus généralement dans le système financier, même si les banques semblent davantage résilientes à un tel choc. Bien que les simulations de modèles suggèrent qu'un choc de rendement obligataire important et prolongé n'aurait pas de retombées significatives en termes de commerce international en l'absence de crises aux États-Unis ou ailleurs, une augmentation induite des rendements obligataire dans d'autres pays, ainsi qu'une importante baisse induite des prix des actions, auraient un effet important sur les économies de l'OCDE et des plus grands pays émergents. Ces derniers pays sont particulièrement vulnérables à de telles retombées étant donné, en général, la faible liquidité de leurs marchés financiers et, dans certains cas, les faibles fondamentaux associés au système bancaire et au financement externe. Aux États-Unis, les autorités devraient s'appliquer à gérer la sortie en douceur et à renforcer la résilience des institutions du système bancaire parallèle de sorte que le risque de ventes précipitées liées à la liquidité soit réduit. Ceci devrait s'accompagner dans les autres pays par des mesures pour accroître la résilience aux chocs de taux d'intérêt, et lorsque le choc se produit, en permettant aux taux de change de d'ajuster de façon flexible et en mettant en œuvre des mesures budgétaires de compensation si une marge de manœuvre est disponible.

Codes JEL : E44 ; E5 ; F4 ; G01 ; G15 .

Mots clé : politique monétaire, retombées, marchés financiers, crise financière. 
TABLE OF CONTENTS

SPILLOVER EFFECTS FROM EXITING HIGHLY EXPANSIONARY MONETARY POLICIES ......... 5

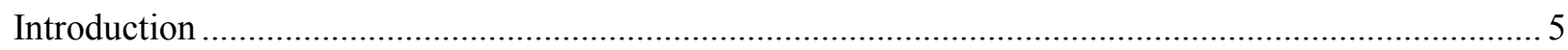

The challenge of normalising monetary policies in the main OECD areas............................................. 5

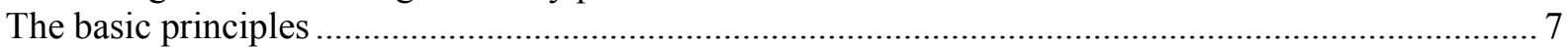

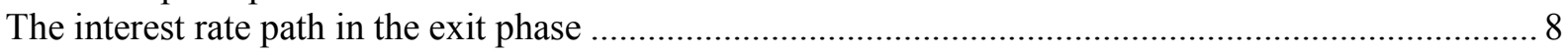

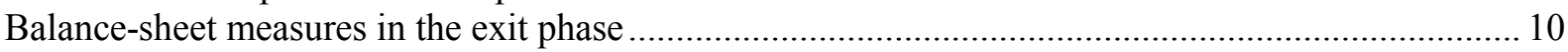

Risks of financial turmoil in the United States and its repercussions on the US economy ..................... 11

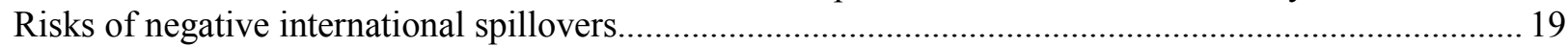

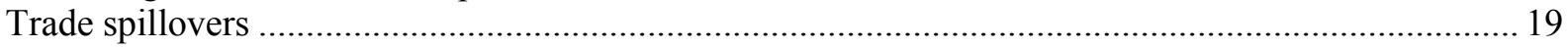

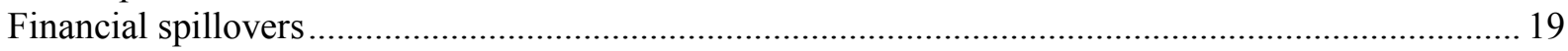

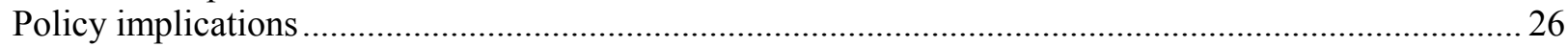

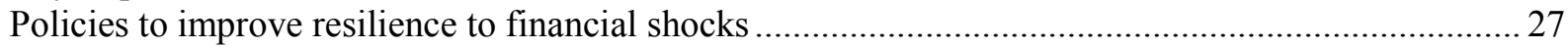

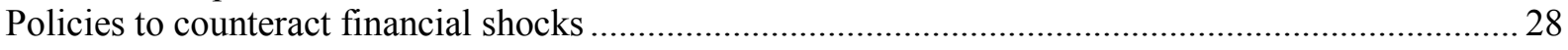

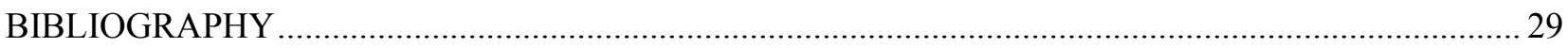

APPENDIX 1. LARGE-SCALE ASSET PURCHASES AND CENTRAL BANK BALANCE SHEETS 31

APPENDIX 2. CO-MOVEMENTS IN FINANCIAL MARKETS ............................................................... 34

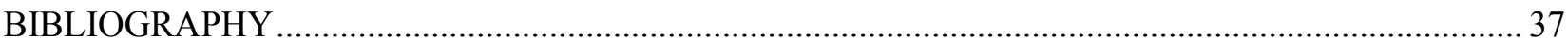

APPENDIX 3. RISKS IN CHINA'S FINANCIAL SYSTEM AND POTENTIAL

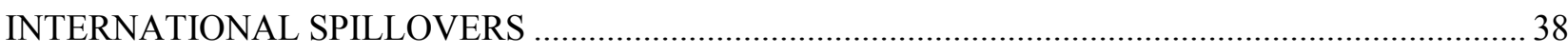

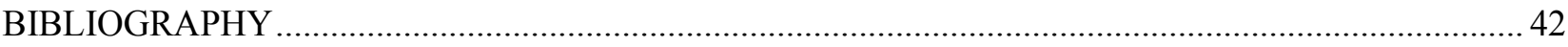

\section{Tables}

1. Selected indicators of the banking sector in the United States ................................................ 14

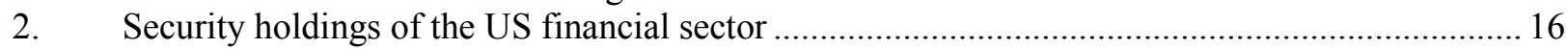

3. Gross trade and financial exposures to the United States.......................................................... 17

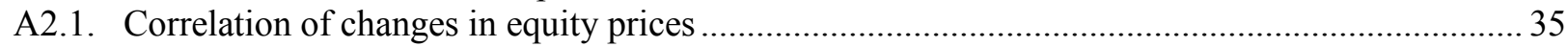

A2.2. Correlation of changes in 10-year government bond yields ..................................................... 35

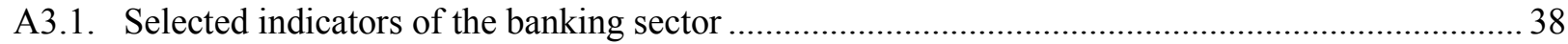

\section{Figures}

1. Central bank assets are well above the pre-crisis levels and policy interest rates below

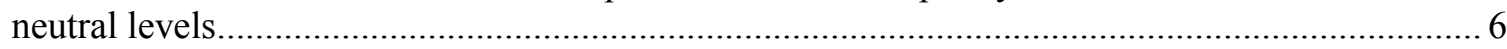

2. Long-term interest rate differentials with the United States................................................... 7

3. Future policy interest rates in the main OECD areas and their determinants................................ 9

4. Changes in financial variables during past tightening cycles and the mid-2013 bond sell-off ..... 11

5. Forward overnight market interest rates in the United States................................................. 12

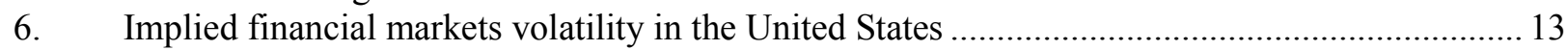

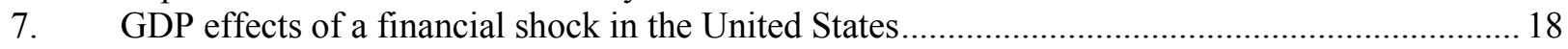

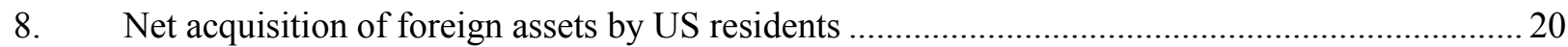

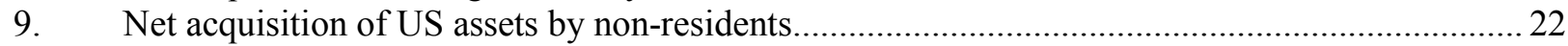

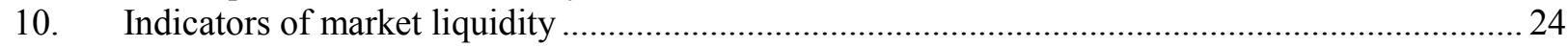

11. The financial turmoil in EMEs in early 2014 was less acute than in mid-2013 .........................25

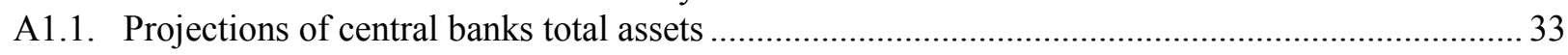

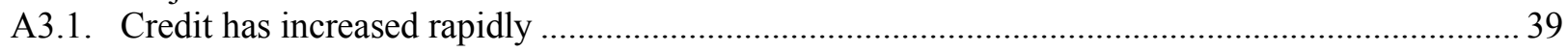


ECO/WKP(2014)12

\title{
SPILLOVER EFFECTS FROM EXITING HIGHLY EXPANSIONARY MONETARY POLICIES
}

\author{
By \\ Łukasz Rawdanowicz, Romain Bouis, Jérôme Brezillon, Ane Kathrine Christensen and Kei-Ichiro Inaba ${ }^{1}$
}

\section{Introduction}

Over the past five years, monetary policy in the main OECD areas has been highly expansionary. Central banks have kept policy interest rates at or close to their effective lower bounds, expanded balance sheets to record high levels (and in some cases still continue to do so), eased collateral policies and provided forward guidance aimed at strengthening expectations about interest rates remaining low for long. This extraordinary stimulus has supported the recovery and risk-taking, thereby affecting asset prices. Such accommodative policies will have to be unwound in due course to prevent overheating and associated risks of asset price bubbles and higher inflation. This process will become necessary as slack diminishes and inflation increases to or above the target. A smooth exit would ultimately imply a better global economic performance, even if it causes temporary headwinds and adjustments of exchange rates and international capital flows. However, it involves risks of disorderly asset price movements and disruptive international spillovers. The US bond sell-off in mid-2013, leading to a steepening of the yield curve, and its spreading to other advanced and emerging market economies (EMEs) is a salient remainder of such possible outcomes, though the muted reaction to the tapering of asset purchases indicates that these economies have become more resilient to such shocks.

This paper first sets out challenges in normalising monetary policies of four central banks: the Bank of England (BoE), the Bank of Japan (BoJ), the European Central Bank (ECB) and the US Federal Reserve (Fed), and assesses likely differences in the nature, timing and speed of monetary policy tightening as factors affecting international spillovers. Then, ensuing risks to financial stability and economic growth in the United States are analysed, followed by an investigation of possible spillovers to other advanced OECD-economies and EMEs. Subsequently, resulting policy implications are discussed. Detailed background analyses are provided in Appendices.

\section{The challenge of normalising monetary policies in the main OECD areas}

With the policy interest rates at or close to the zero lower bound and bloated balance sheets of central banks, the normalisation of monetary policies in the main OECD areas will be challenging. Although not unprecedented, policy rates would have to be increased in the future by nearly 4 percentage points in the United States and the United Kingdom and nearly 3 percentage points in the euro area and Japan to be brought back to their currently estimated steady-state neutral levels, and further increases would be needed if economies were to overheat (Figure 1). However, smaller increases would be required if neutral interest

1. The authors are members of the Macroeconomic Policy Division of the Economics Department. They are indebted to Elena Rusticelli for contributing with model simulations, Shingo Watanabe for initial work on the paper, and to Sveinbjörn Blöndal, Pier Carlo Padoan and Jean-Luc Schneider for their useful comments. The authors are also grateful to Isabelle Fakih and Maartje Michelson for help in the final document preparation. 
rates were to turn out to be lower than expected in the coming years, reflecting slower potential GDP growth after the crisis due to pervasive hysteresis effects. ${ }^{2}$ Following the end of the current quantitative easing $(\mathrm{QE})$ measures, shrinking balance sheets back to the pre-crisis levels would imply a reduction in central banks' assets of around 40\% of GDP in Japan, 20\% of GDP in the United Kingdom and the United States and $10 \%$ in the euro area (Figure 1; Appendix 1). ${ }^{3}$ Such big changes in monetary policy could become destabilising.

Figure 1. Central bank assets are well above the pre-crisis levels and policy interest rates below neutral levels

A. Central bank total assets: past developments and stylised projections ${ }^{1}$

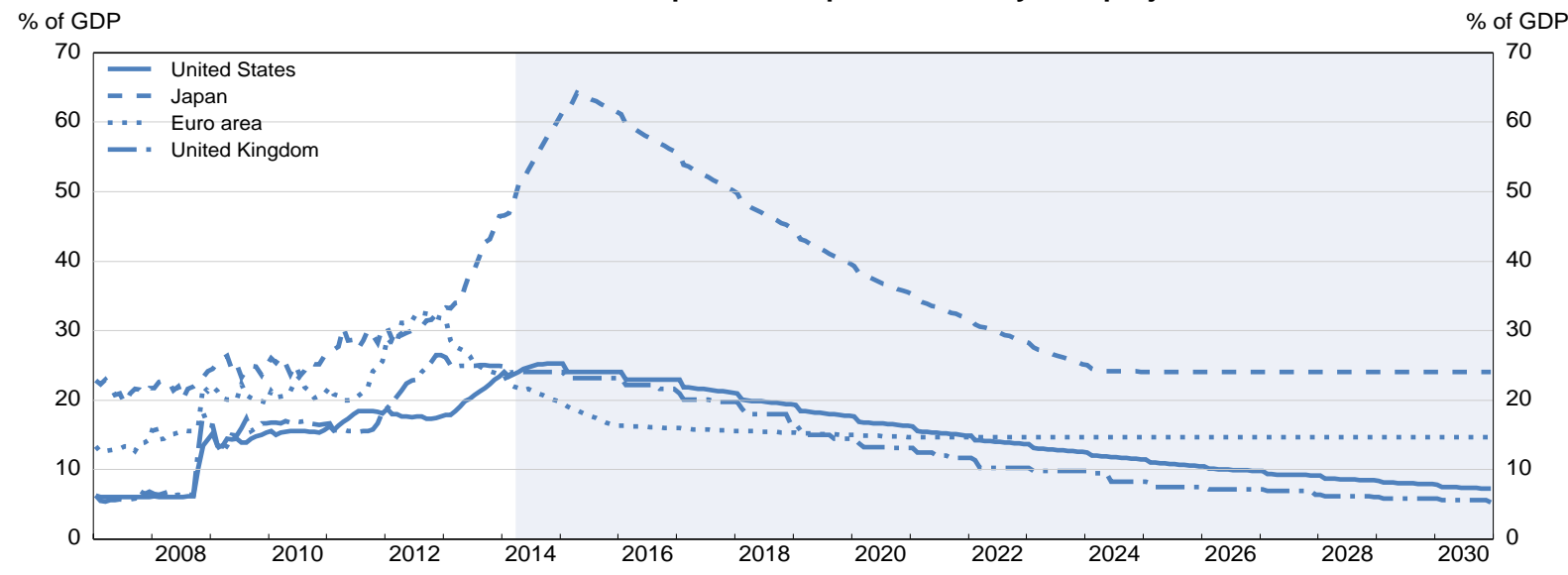

B. Policy interest rates

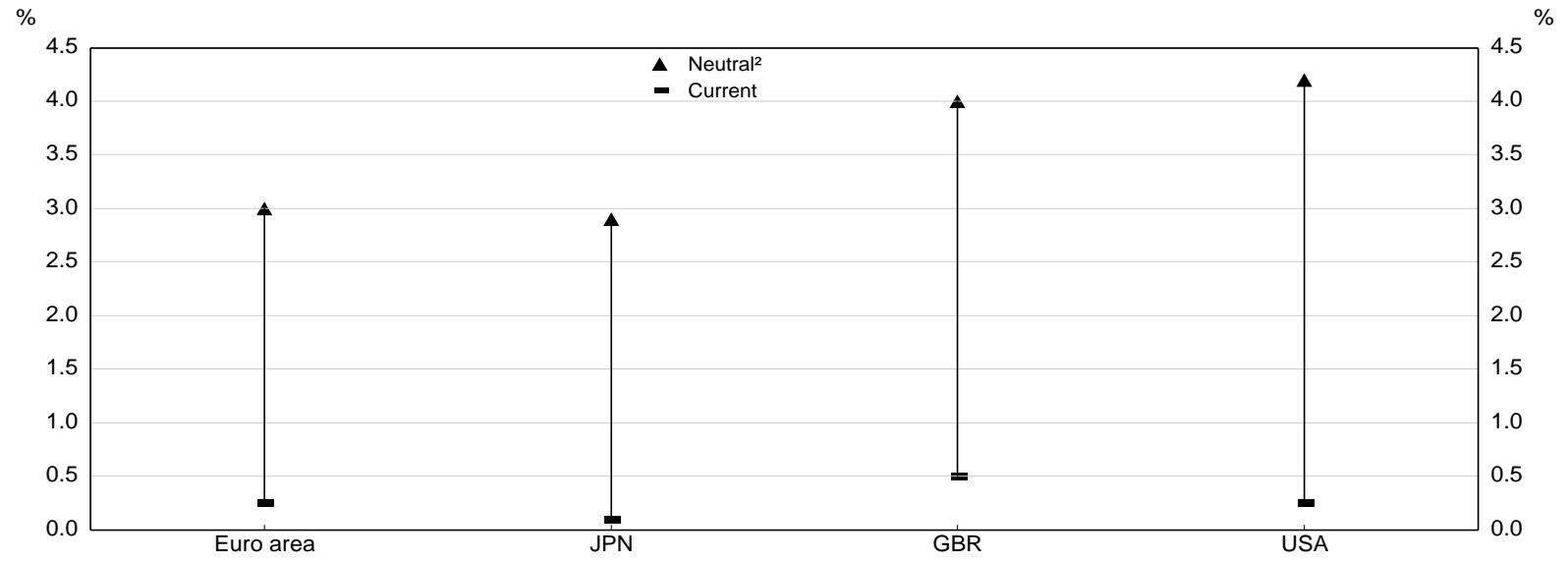

1. See Appendix 1 for explanations about the projections of central banks' total assets.

2. Neutral interest rates are approximated by the sum of inflation targets and the average of projected potential GDP growth rates between 2013 and 2018.

Source: Bank of England; Bank of Japan; European Central Bank; Federal Reserve; OECD Economic Outlook 94 database; and OECD calculations.

2. Neutral rates tend to vary over time and co-move with potential growth rates (Bouis et al., 2013).

3. Central banks could opt for maintaining balance sheets above their pre-crisis levels, but with the return to monetary policy based on controlling short-term interest rates, such a strategy could be costly due to the need to absorb excess liquidity. 


\section{The basic principles}

The prospective exit will be more complicated than in the past due to interactions between policy rate increases and the unwinding of QE. Various combinations of these two policy measures are possible, but changes in policy interest rates are more likely to play the key role for demand management beyond the short term. Effects of the unwinding of QE measures on long-term government bond yields and prices of other asset classes are uncertain, mirroring the uncertainty about the effects of such measures when they were implemented. When standard tools are unconstrained and effective, as should be the case with policy rates during the exit phase, there is less need to rely on unconventional measures. However, the latter could be used together with policy interest rates to refine monetary policy, and both will inevitably interact via market expectations. The planned changes in QE may be interpreted by market participants as a signal of changes in the reaction function of the central bank and affect expectations about future interest rate increases, as was the case in the United States, where discussions in mid-2013 about tapering of security purchases by the Fed prompted market participants to expect sooner and stronger policy interest rate increases (see below). However, this is not inevitable: the Fed's decisions to reduce the pace of asset purchases between December 2013 and March 2014 did not materially affect market expectations of the future policy rate path.

If monetary tightening were ultimately going to be primarily based on policy rates, then it would be desirable to cease additional QE before raising interest rates to avoid blurred signals about policies. The timing and pace of tapering QE should be determined by the balance of marginal costs and benefits and the assessment of how much incremental stimulus is still needed (Rawdanowicz et al., 2013). The cost-benefit balance of asset purchases becomes less favourable when the start of the exit from low policy rates is closer in time and asset holdings are higher. Larger central bank's balance sheets could imply higher costs of remunerating reserve balances and realised losses, with threats to central bank independence, and could be more difficult to reduce smoothly over the longer term. The ultimate pace of lowering the size of the balance sheets should depend on implications of asset sales on financial markets and the effectiveness and costs of available measures to absorb excess liquidity (see below).

Figure 2. Long-term interest rate differentials with the United States
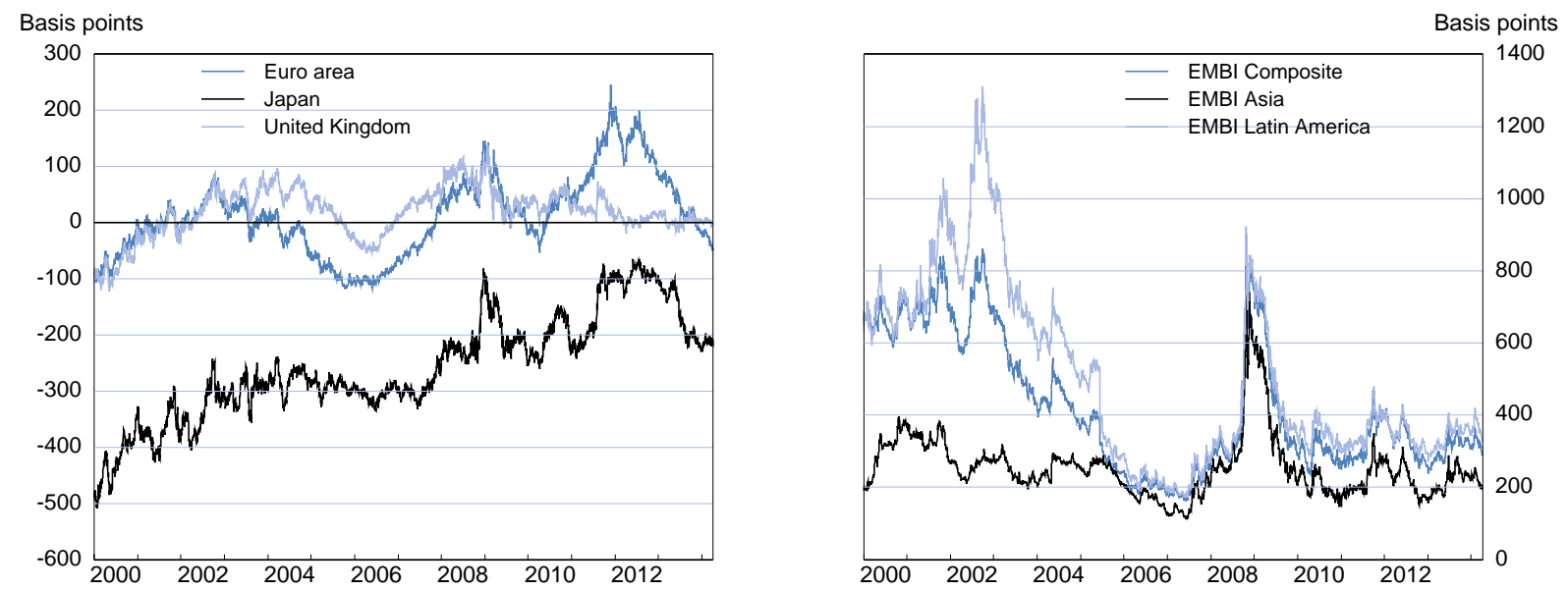

Note: The differentials are calculated based on 10-year government bond yields for the OECD economies and on the JPMorgan Emerging Market Bond Index (EMBI) for emerging market economies.

Source: Datastream. 


\section{The interest rate path in the exit phase}

The timing of exiting from highly accommodative monetary policy is likely to differ across main OECD areas, with the United States and the United Kingdom, starting to normalise monetary policy sooner than Japan and the euro area. This implies that risks of heightened financial market volatility are likely to occur first in the United States, as already observed in May-August 2013, with either changing long-term interest rate differentials (Figure 2) or contagion to long-term yields across countries.

The modified forward guidance, conditional on Fed's current projections, suggests that policy interest rate increases in the United States will likely not take place until at least early $2015 .^{4}$ A similar timing of policy rate increases could be expected in the United Kingdom. ${ }^{5}$ This is also the case in the euro area, where the ECB's forward guidance is based on the outlook for inflation extending into the medium term. The latest Eurosystem staff projections foresee inflation in 2015 to fall significantly short of the inflation target, implying that the interest rates will be maintained at the current, or lower, level for a long period. In Japan, though no forward guidance regarding the future path of interest rates has been provided, the BoJ is committed to continue the quantitative and qualitative monetary easing until achieving firmly positive inflation and close to the $2 \%$ inflation target. As the BoJ expects the annual inflation rate, adjusted for the effects of the consumption tax hikes, to reach around $2 \%$ only in fiscal year 2015, it would be consistent to maintain the current policy rates at least until end-2015.

Financial market participants expect a similar timing of policy interest rate increases (around mid-2015) in the United Kingdom and the United States (Figure 3). In the euro area and Japan, financial market participants, however, do not expect the rates to rise before mid-2016 and end-2016, respectively. Private forecasters also project rising policy interest rates, with the first increases anticipated in the United Kingdom and in the United States in 2015.

4. With the unemployment rate declining to close to $6 \frac{1}{2}$ per cent, the Federal Reserve modified its forward guidance in March 2014 by removing the reference to the initially announced unemployment threshold for considering rate increases, and indicating that it would consider a wide range of indicators, including indicators on labour and financial markets and inflation. It also stated that it would be likely appropriate to maintain the current target range for the federal funds rate "for a considerable time" after the asset purchase programme ended, which is likely to happen in the latter part of 2014, especially if projected inflation continued to run below the $2 \%$ target, and longer-term inflation expectations remained well anchored. According to the March 2014 FOMC members' projections, 13 out of 16 participants thought that the first increase in the federal funds rate would not be warranted until sometime in 2015 and 10 of them saw the federal fund rate at least at $1 \%$ in end-2015.

5. The forward guidance in the United Kingdom was modified in February 2014 to state the principles to be used after the unemployment threshold is reached. The Bank of England would seek to remove spare capacity in the economy over the next two to three years, while keeping inflation close to the target and to this end it judged that there was scope for the economy to recover further before the policy rate is raised.

6. In the United States, according to the March 2014 survey of primary dealers, the median response implied that the federal rate would be at $0.63 \%$ in the second half of $2015,2 \%$ in the second half of 2016 and $3.25 \%$ in the second half of 2017 , with the median of the most likely timing of the first interest rate hike 2015Q3. According to the 2014Q1 Philadelphia Fed Survey of Professional Forecasters, the mean expectation of the 3-month Treasury bill rate was $0.1 \%$ in $2014,0.4 \%$ in 2015 and $1.6 \%$ in 2016 . In the United Kingdom, in February 2014, independent forecasters on average did not expect interest rate hikes before 2015 , with the official bank rate projected to increase to $0.9 \%$ in $2015,1.6 \%$ in 2016 and $2.2 \%$ in 2017 (HM Treasury, 2014). Long-term projections of policy or short-term interest rates are not available for the euro area and Japan. 
Figure 3. Future policy interest rates in the main OECD areas and their determinants

A. Expected overnight market interest rates ${ }^{1}$ Per cent

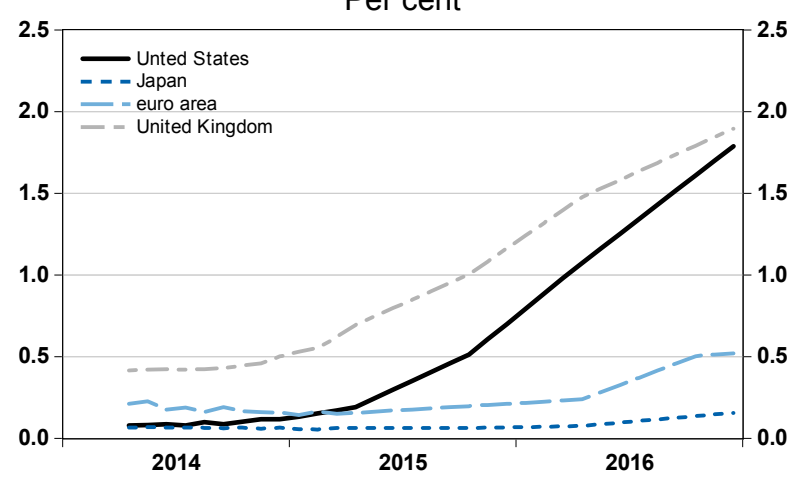

C. Output gap

Per cent of potential output

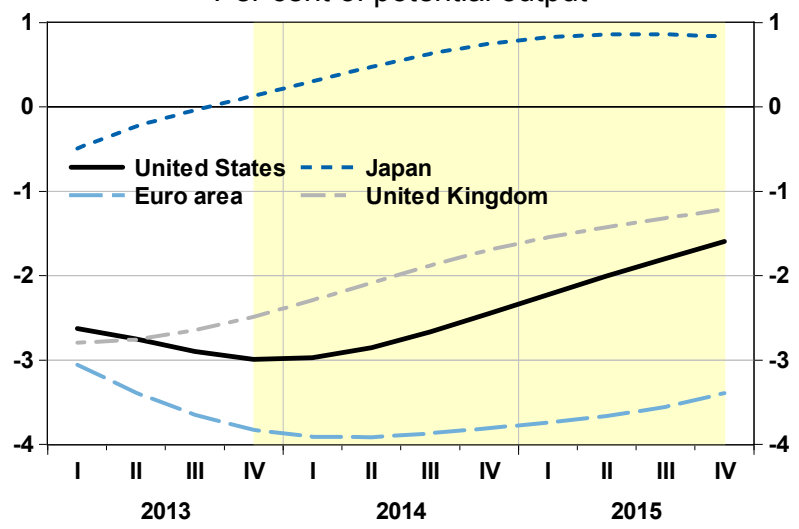

E. Unemployment gap

Percentage points

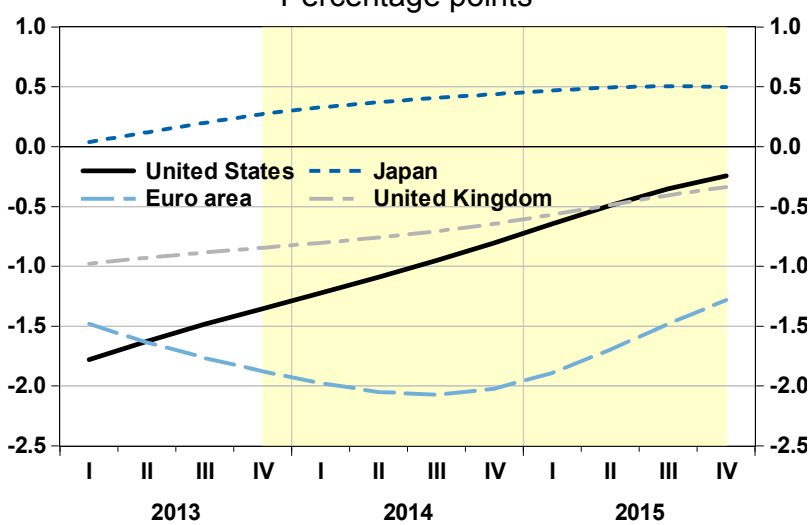

B. Policy interest rates in $2015 Q 4^{2}$ Per cent

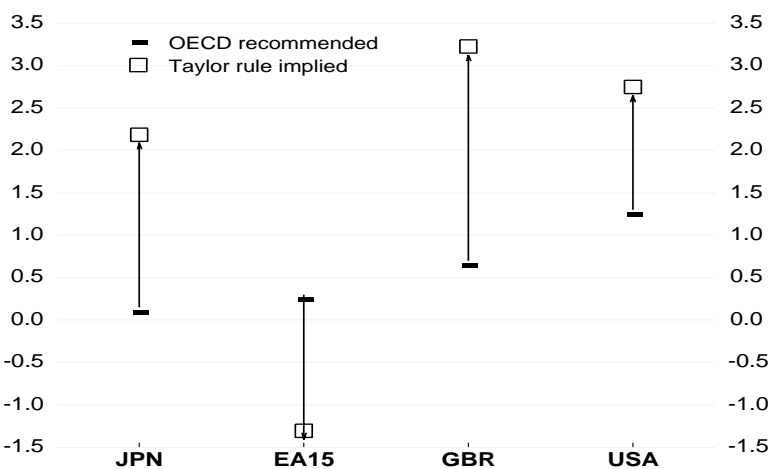

\section{Core inflation}

Per cent year-on-year increase

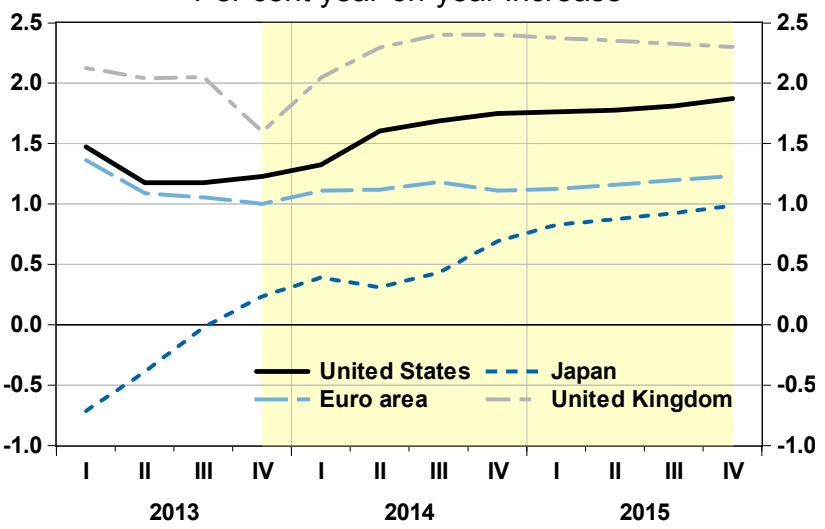

F. Unemployment rate

Per cent of labour force

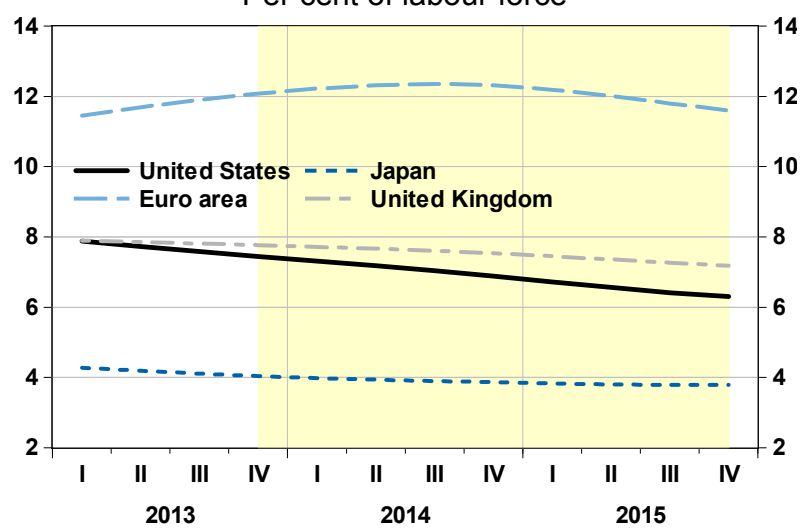

1. Forward overnight market interest rates derived from OIS curves as of 4 April 2014 .

2. The Taylor rule is $i=r^{*}+p+0.5\left(p-p^{*}\right)+$ gap, where $r^{*}$ is the neutral real interest rate, $p$ is the $y$-o-y core inflation rate, $p^{*}$ is the inflation target, and gap is the output gap. The core inflation for the United States refers to the rate of change of the deflator for core personal consumption expenditure. The neutral real interest rates are set to the annual growth rate of potential output.

3. Projections of core inflation in Japan are adjusted for the planned increase in the consumption tax rate in 2014 and 2015.

Source: OECD calculations based on Bloomberg data; and OECD Economic Outlook 94 database. 
The OECD projections from November 2013 (OECD, 2013b) call for broadly similar policy interest rate paths in the United Kingdom and the United States as currently embedded in financial markets. Conditional on downside risks not materialising and receding gradually and on the recoveries proceeding as projected, it would be appropriate for the United States to increase gradually policy rates from early 2015 and in the United Kingdom to do so later in that year. Given the OECD projections from November 2013 of a significant narrowing of output and unemployment gaps and inflation at the respective targets by 2015, the levels of interest rates in the United States and the United Kingdom assumed by the OECD by end-2015 will still be significantly below their neutral levels and levels implied by a simple Taylor rule (Figure 3). This can be justified by the persistence of downside risks, and the need to boost low employment after the crisis and accommodate drag from still ongoing fiscal consolidation, even if expected to be smaller than in the preceding years. However, it implies a possible need for a fast increase of policy rates during 2016 and 2017 to avoid overheating of the economy, asset price bubbles and inflation expectations becoming un-anchored. No need is seen in the OECD November 2013 projections for higher policy rates in either the euro area or Japan at least until end-2015, which is consistent with the implied monetary policy stance by the ECB and the BoJ.

\section{Balance-sheet measures in the exit phase}

The future evolution of central bank assets is uncertain in view of little guidance from central banks (Appendix 1) and limited past experiences with the unwinding of unconventional tools. Based on current policies, in the first half of 2014, balance sheets will continue to shrink in the euro area and remain unchanged in the United Kingdom, while they are set to expand in Japan and the United States (Figure 1; Appendix 1). Looking further ahead, it was argued in the November 2013 OECD Economic Outlook that it would be appropriate to stop asset purchases in the United States, while such operations needed to continue in Japan; in the euro area, QE-like operations would become necessary if disinflationary pressures were to persist or if financial fragmentation were to intensify again (OECD, 2013b).

With the exception of the euro area, lowering the size of central bank balance sheets to their pre-crisis levels could be protracted, but may still have non-negligible impact on financial markets, given the large adjustment required. The expansion of ECB's assets was primarily due to long-term refinancing operations (LTROs), and the evolution of balance sheets will depend on the willingness of euro area banks to use LTROs and exit will be automatic upon the maturing of such loans. If no further LTROs funds are taken, the ECB's balance sheet would shrink to roughly the pre-crisis level already in 2015 (Figure 1; Appendix 1). In contrast, in Japan, the United Kingdom and the United States, the reduction of central banks' balance sheets would have to involve discretionary decisions, based on the implications for financial stability, liquidity and inflation expectations. The massive size of accumulated assets would call for a gradual reduction to avoid excessive financial market volatility, while concerns about excess liquidity and related risks of asset bubbles and higher inflation in the absence of other policy measures may call for a faster downsizing. With well-anchored inflation expectations and effective measures to drain excess liquidity being put in place, ${ }^{7}$ central banks could opt for keeping assets to maturity. In such a case, it would take around 15 years in the United Kingdom and the United States and around 10 years in Japan to return the size of their balance sheets in relation to GDP close to pre-crisis levels (Figure 1; Appendix 1).

7. Various instruments are available, including the deposit rate, reverse market operations, term deposits, issuance of central bank bills and required reserves (Minegishi and Cournède, 2010). The last measure, when combined with the remuneration of reserves below market interest rates, could also help reduce central banks' net interest expenses. 


\section{Risks of financial turmoil in the United States and its repercussions on the US economy}

The pace of monetary policy normalisation in the United States and its pass-through to long-term interest rates and other domestic asset prices will determine the direct impact on the real economy and prices as well as financial stability. As in previous upturns, the normalisation of monetary policy and the associated re-pricing of financial instruments will act as a headwind for the economy, all other things being equal. However, as long as this process is gradual and motivated by a strengthening of activity, it should not excessively restrain growth or risk unsettling financial stability and should prevent new imbalances to build up. This is particularly the case if the underlying momentum of the economy is strong, equity markets are buoyant and the exchange rate does not appreciate strongly. Indeed, during the tightening cycles in 1994-95, 1999-2000 and 2004-06, US share prices increased between $2 \%$ and $11 \%$, the growth rate was between $3 \%$ and $4 \%,{ }^{8}$ and the dollar nominal effective exchange rate appreciated only slightly in the first two periods, while it depreciated by 6\% in 2004-06 (Figure 4). However, risks of a less favourable scenario cannot be excluded, given remaining vulnerabilities in the financial system and the still weak economy. A large increase in longer-term government bond yields, leading to the steepening of the yield curve, could be particularly deleterious.

Figure 4. Changes in financial variables during past tightening cycles and the mid-2013 bond sell-off

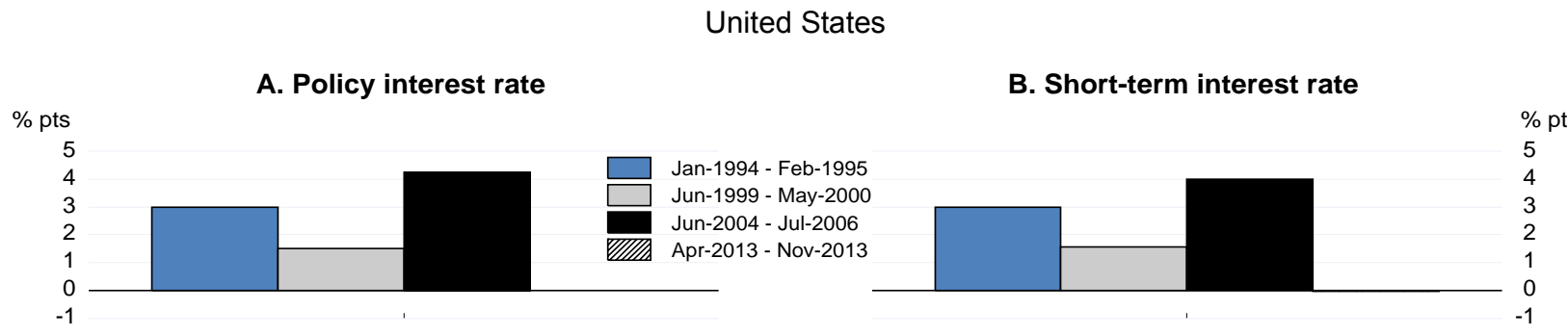

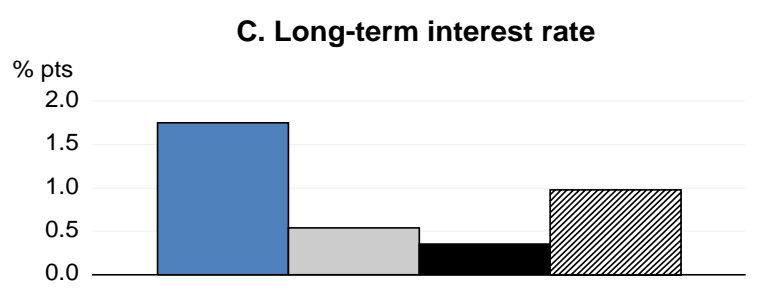

E. Nominal effective exchange rate

$\%$

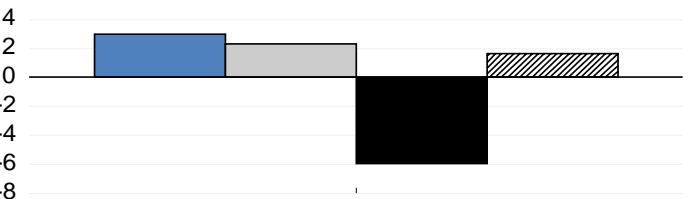

D. Share prices

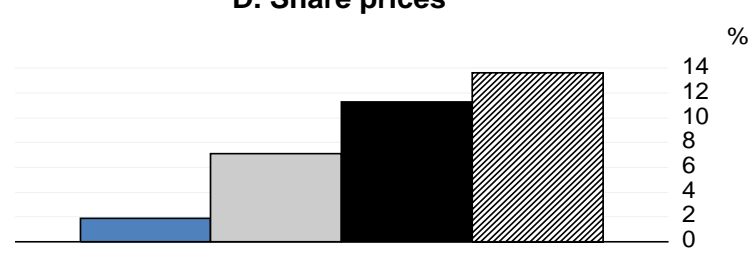

F. Real effective exchange rate ${ }^{1}$

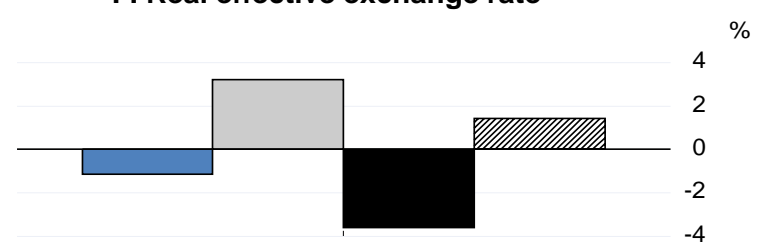

1. Based on CPI.

Note: Changes are calculated based on data at monthly frequency.

Source: Datastream; and OECD.

8. The growth rate is measured as an average of quarter-on-quarter annualised growth rates between the start of interest rate increases and two quarters after the end of monetary tightening. 
Figure 5. Forward overnight market interest rates in the United States

$\%$

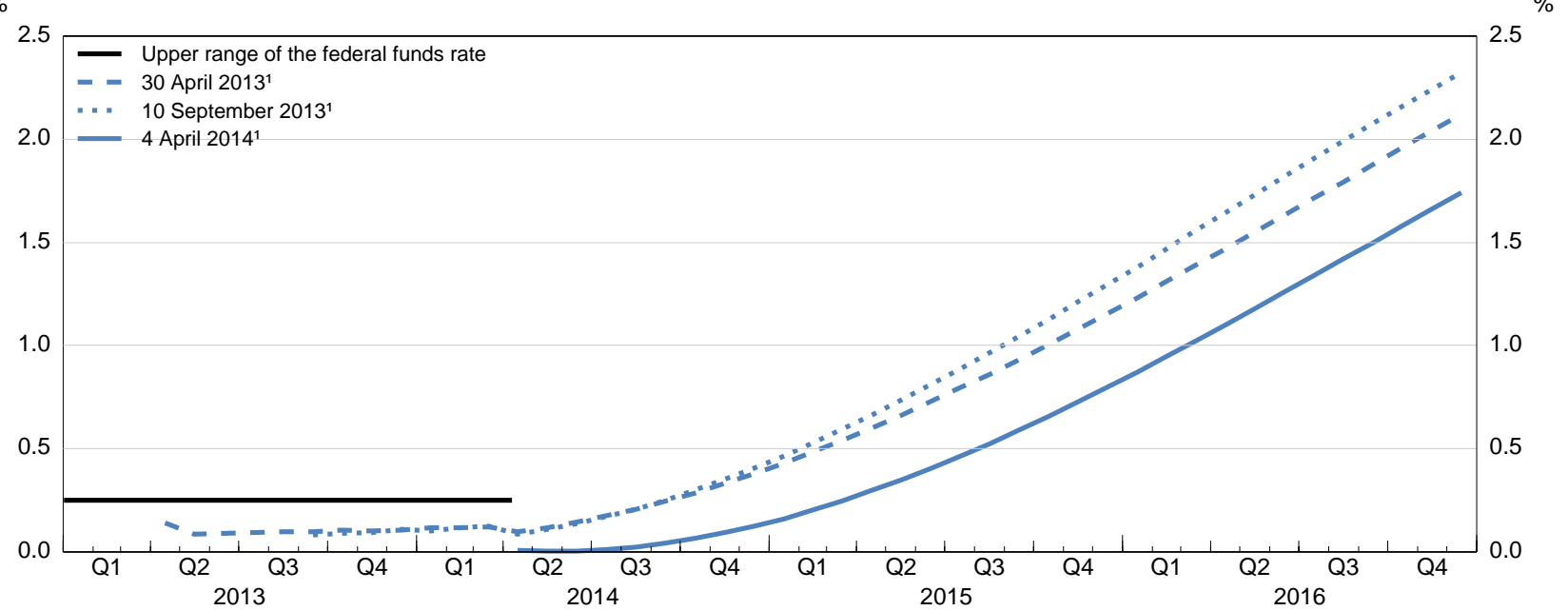

1. Derived from overnight index swap rates.

Source: OECD calculations based on Bloomberg data.

Indeed, the turbulence in US financial markets in May-August 2013 demonstrates that market reactions can be abrupt. Amid signs of a strengthening economy, Fed communication about the likely course of asset purchase programmes triggered a bond sell-off, with 10-year government bond yields increasing by around 130 basis points, and contributed to large gyrations in equity prices. This abrupt reaction can be explained by expectations of less accommodative monetary policy, increased uncertainty and self-reinforcing price dynamics. In spite of the intentions of the Fed to separate decisions about asset purchases and policy rates, the bond yield increase likely reflected changes in market participants' expectations about both measures and thus drove both term premia and future short-term interest rates higher (Bernanke, 2013). Future interests rates derived from financial market instruments indeed increased (Figure 5). Term premia rose as well as investors reduced somewhat their expectations of the duration of the asset purchase programme, but this is unlikely to explain the entire change in 10-year Treasury yields. ${ }^{9}$ Beyond this impact, term premia could have also risen due to growing uncertainty about future monetary policy, as reflected in a higher volatility of financial indicators (Figure 6) ${ }^{10}$ Moreover, price movements

9. It would have required massive change in market participants' expectations of the duration of asset purchases by the Fed to fully explain the 130-basis point increase. Selected empirical evidence on QE in the United States suggests that on average each $\$ 100$ billion of asset purchases has increased 10-year Treasury bond yields by 7 basis points (Appendix 1 in Bouis et al., 2013). Thus, a 130-basis point decline in yields would imply that market participants expected Fed's security holdings to be reduced by around $\$ 1.9$ trillion relative to previous expectations. This would be consistent with bringing forward the expected timing of ending the existing asset purchase programme of $\$ 85$ billion per month by almost two years on the hypothetical assumption that such purchases were kept at this level until they were terminated, and not gradually tapered as planned.

10. Term premia in the United States have been estimated to be historically low and even negative over the past 2-3 years (Turner, 2013; and Adrian et al., 2013a). However, Cochrane (2007) argues that model estimates of term premia are highly uncertain. Bauer et al. (2013) and Bauer and Rudebusch (2013) show, in particular, that a small-sample bias of the maximum likelihood estimates of affine term structure models, frequently applied in the literature, results in a downward bias in estimates of US term premia in the recent period. 
could also have been amplified by investors' trading strategies based on value-at-risk models, with the sudden increase in volatility leading to an algorithm-driven unwinding of positions, and by diminished dealers' capacity and willingness to buy and sell in the volatile environment. Indeed, dealers reduced their market-making activities in May-July 2013 (Adrian et al., 2013b). ${ }^{11}$

Figure 6. Implied financial markets volatility in the United States
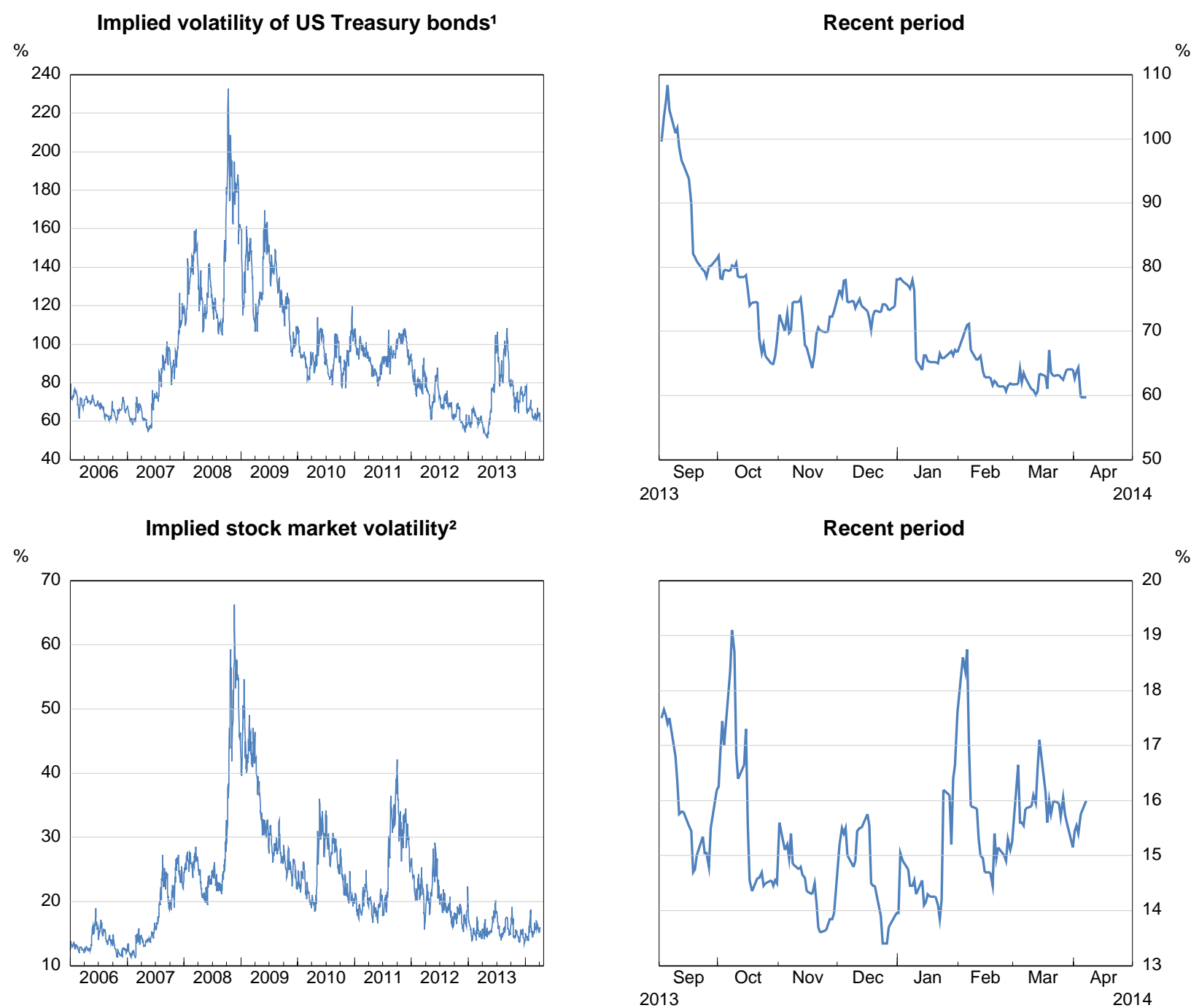

1. A market estimate of future US Treasury bond yield volatility as measured by the 3-month Merrill Option Volatility Estimate (MOVE) index.

2. Based on the options from the Chicago Board Option Exchange Market for the S\&P 500 stock index. Implied volatility can be interpreted as market expectation of risk (future volatility) and is derived from at-the-money call option prices (interpolated).

Source: Datastream.

11. Adrian et al. (2013b) suggest that dealers' behaviour was driven more by unwillingness to trade rather than capital constrains in the view of the general market reassessment of bond valuations and higher interest rate risk in the context of heightened uncertainty about the monetary policy stance. 
Table 1. Selected indicators of the banking sector in the United States

\begin{tabular}{|c|c|c|c|c|}
\hline & \multirow{2}{*}{$\begin{array}{l}\text { All national depository } \\
\text { institutions insured by } \\
\text { FDIC }\end{array}$} & \multicolumn{3}{|c|}{ US Globally Systematic Important Banks ${ }^{1}$} \\
\hline & & $\min$ & mean & $\max$ \\
\hline \multicolumn{5}{|c|}{ Tier 1 capital to risk-weighted assets, \% } \\
\hline 2005 & 10.6 & 8.3 & 9.0 & 11.7 \\
\hline 2006 & 10.5 & 8.2 & 9.5 & 13.7 \\
\hline 2007 & 10.1 & 6.9 & 8.4 & 11.2 \\
\hline 2008 & 9.9 & 7.8 & 13.4 & 20.3 \\
\hline 2009 & 11.6 & 9.3 & 12.8 & 17.7 \\
\hline 2010 & 12.7 & 11.2 & 14.2 & 20.5 \\
\hline 2011 & 12.9 & 11.3 & 14.2 & 18.8 \\
\hline 2012 & 13.1 & 11.8 & 15.0 & 19.1 \\
\hline 2013 & 13.1 & 11.9 & 14.5 & 17.3 \\
\hline \multicolumn{5}{|c|}{ Tier 1 capital to total assets, $\%$} \\
\hline 2005 & 8.0 & 5.2 & 6.0 & 6.6 \\
\hline 2006 & 7.9 & 4.8 & 5.8 & 6.2 \\
\hline 2007 & 7.6 & 4.1 & 5.3 & 6.4 \\
\hline 2008 & 7.2 & 6.1 & 6.9 & 8.1 \\
\hline 2009 & 8.4 & 6.0 & 6.9 & 7.6 \\
\hline 2010 & 8.7 & 5.5 & 7.1 & 8.7 \\
\hline 2011 & 8.8 & 4.7 & 6.8 & 8.7 \\
\hline 2012 & 8.7 & 4.7 & 6.9 & 8.9 \\
\hline 2013 & 9.1 & 4.9 & 7.2 & 9.2 \\
\hline \multicolumn{5}{|c|}{ Cash and near cash assets to total liabilities, \% } \\
\hline 2005 & 4.5 & 1.5 & 2.8 & 3.5 \\
\hline 2006 & 4.4 & 0.8 & 2.4 & 3.4 \\
\hline 2007 & 4.5 & 1.0 & 2.6 & 3.9 \\
\hline 2008 & 8.8 & 1.3 & 6.4 & 27.8 \\
\hline 2009 & 9.0 & 1.4 & 3.6 & 6.1 \\
\hline 2010 & 8.4 & 1.4 & 4.2 & 10.4 \\
\hline 2011 & 10.5 & 1.1 & 7.5 & 32.4 \\
\hline 2012 & 11.1 & 1.3 & 7.2 & 29.5 \\
\hline 2013 & 13.1 & 1.3 & 6.7 & 26.0 \\
\hline \multicolumn{5}{|c|}{ Share of short-term funding in total funding, \% } \\
\hline 2005 & .. & 8.4 & 34.8 & 70.0 \\
\hline 2006 & $\begin{array}{l}. . \\
.\end{array}$ & 6.7 & 27.6 & 44.2 \\
\hline 2007 & $\begin{array}{l}. . \\
.\end{array}$ & 13.1 & 26.1 & 38.3 \\
\hline 2008 & $\begin{array}{l}. . \\
.\end{array}$ & 9.8 & 21.9 & 34.1 \\
\hline 2009 & $\begin{array}{l}. . \\
. .\end{array}$ & 7.4 & 21.3 & 28.0 \\
\hline 2010 & $\begin{array}{l}. . \\
. .\end{array}$ & 5.2 & 20.8 & 28.9 \\
\hline 2011 & $\begin{array}{l}. . \\
. .\end{array}$ & 4.1 & 18.5 & 28.5 \\
\hline 2012 & $\begin{array}{l}. . \\
. .\end{array}$ & 2.8 & 17.7 & 27.5 \\
\hline 2013 & $\begin{array}{l}. . \\
. .\end{array}$ & 1.8 & 18.0 & 27.7 \\
\hline
\end{tabular}

1. Includes: Bank of America, Bank of New York Mellon, Citigroup, Goldman Sachs, JP Morgan Chase, Morgan Stanley, State Street and Wells Fargo.

Note: Tier 1 capital includes common stockholders' equity, qualifying preferred stock and minority interest less goodwill and other adjustments. Risk-weighted assets are calculated by weighing each type of asset relative to its risk. Cash and near cash assets include total cash and balances due from depository institutions including both interest-bearing and non-interest-bearing balances. The share of short-term funding in total funding is defined as the ratio of short-term borrowings to the sum of short and long-term borrowings, total deposits and repurchase agreements.

Source: Bloomberg; FDIC Statistics on Depository Institutions Report; and OECD calculations. 
Following the developments in May-August 2013, future swift changes in asset prices cannot be excluded. Even if the Fed's decisions to reduce the pace of asset purchases between December 2013 and March 2014 have not lead to large market volatility, market participants can still react abruptly to prospective announcements about QE policies. Moreover, they may be surprised by the pace of policy interest rate increases or by new information about it. The current forward guidance also does not indicate what is going to happen once the tightening cycle starts. If the Fed sticks to its intention to maintain low policy interest rates for longer than would be normally expected, market participants could expect that the monetary policy stance may have to be subsequently tightened in an abrupt way.

While future tapering and interest rate increases may trigger a sudden drop in asset prices, the capacity of the US banking system to withstand such a shock appears to have improved. Banks - especially the largest ones - have raised loss-absorbing capital and liquid buffers (Table 1), and further increases in these buffers are in the pipeline. ${ }^{12}$ Nevertheless, net interest income of US banks could be negatively affected given that banks' sensitivity to interest rate risk has increased compared with the period prior to the crisis, even if reliance on short-term funding has decreased (FSOC, 2013; and IMF, 2013). This reflects, among other things, a higher share of long-term mortgage and commercial loans, which are often fixed at low interest rates, and rising non-maturity deposits. ${ }^{13}$ However, a direct impact of a decline in government bond prices on banks' balance sheets would be relatively small. Stylised calculations suggest that a 1-percentage point upward parallel shift of the yield curve would lead to capital losses of around $10 \%$ of Tier 1 capital (Box 1.5 in OECD, 2013b). ${ }^{14}$ This presumption is reinforced by the Fed's 2014 stress test of complex bank holding companies, which suggests that, in a severely adverse scenario - accounting for a broader set of feedbacks and involving a deep recession in the United States, Europe and Japan, large declines in asset prices and rising risk premia, and a marked economic slowdown in developing Asia, they would incur heavy losses and their leverage ratios would decline by more than 3 percentage points on average but would still be around 8\% (Board of Governors of the Federal Reserve System, 2014). ${ }^{15}$

Some shadow banking institutions may, however, be vulnerable to increases in interest rates that could trigger liquidity problems and disruptive fire sales. This is because some of them have large holdings of government and agency securities relative to total assets (Table 2) that are used as collateral for shortterm funding and some are characterised by low equity buffers:

- Money market funds (MMFs) are susceptible to runs by their depositors, owing to the fact that they issue stable-value demandable liabilities with no capital buffer or other explicit loss-absorption capacity (FSOC, 2013; and Stein, 2013). Losses on their holdings of government and agency securities could trigger such runs. This could have considerable ramifications for the repurchase agreements (repos) market as MMFs are the largest cash investor, increasing rollover risks for other

12. In February 2014, the Fed strengthened supervision and regulation of large U.S. bank holding companies and foreign banking organisations by increasing the required regulatory capital held by the most systemically significant US banks to an equivalent of 5\% of total assets and by their insured depository subsidiaries to $6 \%$ of total assets for them to be considered well capitalised; and by strengthening the liquidity positions of large financial institutions by requiring them to hold high-quality liquid assets in an amount equal to or greater than the projected cash outflows minus the projected cash inflows during a 30 day period. Both measures are stricter than the corresponding Basel III regulations.

13. Non-maturity deposits include passbook accounts, money market deposit accounts, and non-interest-bearing demand deposits.

14. A steepening of the yield curve so that the long end increases by 1 percentage point would have even a smaller impact. A steepening is likely ahead of anticipated tightening.

15. The majority of total losses (around 70\%) stems from losses on loans, whereas only around a quarter of total losses is explained by trading, counterparty and realised security losses. 
financial institutions, notably agency mortgage-backed securities (MBS) real estate investment trusts (REITs) and broker-dealers.

- Agency MBS REITs could be seriously affected by higher interest rates as the value of their collateral in repos would fall and give rise to margin calls. In the absence of significant equity cover, as the trusts cannot build up equity buffers through retained earnings, this could trigger a fire sale of their holdings of MBS, reinforcing the adverse price dynamics, and in turn increase mortgage rates appreciably. Agency REITs are still relatively small, with financial assets around $\$ 450$ billion $(2.6 \%$ of GDP), but over the past three years they have expanded rapidly, and they contributed to the fire sales observed during the mid-2013 bond sell-off (IMF, 2013; and FSOC, 2013). ${ }^{16}$

- Broker-dealers could be also affected by rising interest rates due to their exposure to liquidity and interest rate risks. Because their cash management basically depends on security repos and credits, increases in interest rates will reduce the value of collateral such as Treasuries and agency MBS. In addition, they are susceptible to liquidity risks during market stress, especially in the tri-party repo market with the heavy involvement of MMFs (Stein, 2013). Some of these risks have been mitigated by the shrinking of brokers-dealers' total financial assets (by around a quarter since 2007) and falling leverage even if it remains above the leverage at commercial banks (FSOC, 2013). However, their net holdings of government securities moved from negative to positive over the past five years, making them more susceptible to potential capital losses.

A significant and protracted tightening of financial conditions would materially hit the real economy. In an extreme case of a 2-percentage point increase in long-term interest rates during one year, macromodel simulations suggest that around $1 \frac{1}{2}$ percentage points would be subtracted from growth in the United States in the first year. ${ }^{17}$ It would also lead to negative spillovers to other economies, in particular EMEs, with ensuing feedback on the US economy (see below and Figure 7), though such feedbacks from other economies, in the absence of tail events, are not large in the macro-model applied (Ollivaud et al., 2014).

Table 2. Security holdings of the US financial sector

\begin{tabular}{|c|c|c|c|c|c|c|c|c|c|c|c|c|c|}
\hline & \multirow{2}{*}{\multicolumn{3}{|c|}{ Treasury securities }} & \multicolumn{3}{|c|}{$\begin{array}{c}\text { Agency \& GSE-backed } \\
\text { securities }\end{array}$} & \multirow{2}{*}{\multicolumn{3}{|c|}{$\begin{array}{l}\text { Corporate and foreign } \\
\text { bonds } \\
\text { assets }\end{array}$}} & \multirow[t]{2}{*}{$\begin{array}{l}\text { FFs and } \\
\text { Repos }{ }^{1}\end{array}$} & \multirow{2}{*}{\multicolumn{3}{|c|}{$\begin{array}{c}\text { Total financial assets } \\
\text { USD trillions }\end{array}$}} \\
\hline & & & & & of total & inancial as & & & & & & & \\
\hline & 2011 & 2012 & 2013 & 2011 & 2012 & 2013 & 2011 & 2012 & 2013 & 2013 & 2011 & 2012 & 2013 \\
\hline Financial business & 5.4 & 5.9 & 6.1 & 8.0 & 8.0 & 8.0 & 10.2 & 10.2 & 9.9 & -1.2 & 69.2 & 72.2 & 77.5 \\
\hline U.S.-chartered depository institutions & 1.7 & 1.8 & 1.7 & 13.7 & 14.2 & 13.8 & 4.7 & 4.6 & 4.5 & -1.4 & 11.5 & 11.8 & 12.4 \\
\hline Property-casualty insurance companies & 6.8 & 6.5 & 6.0 & 8.7 & 8.3 & 7.7 & 25.2 & 26.4 & 25.8 & 0.0 & 1.4 & 1.4 & 1.5 \\
\hline Life insurance companies & 3.2 & 3.2 & 3.1 & 7.1 & 6.6 & 6.2 & 39.5 & 38.6 & 37.3 & -0.1 & 5.3 & 5.5 & 5.8 \\
\hline Private and public pension funds & 3.6 & 4.3 & 4.3 & 2.5 & 2.7 & 2.7 & 6.0 & 5.3 & 4.6 & 0.0 & 14.2 & 14.9 & 15.9 \\
\hline Money market mutual funds & 14.2 & 18.0 & 18.0 & 14.4 & 13.2 & 13.3 & 4.9 & 3.9 & 3.7 & 18.3 & 2.6 & 2.5 & 2.6 \\
\hline Mutual funds & 5.4 & 6.0 & 6.0 & 8.8 & 9.4 & 8.0 & 16.8 & 17.8 & 17.8 & 3.1 & 8.1 & 9.0 & 10.7 \\
\hline M-REITs & - & - & - & 75.9 & 79.8 & 72.0 & 7.3 & 5.9 & 7.7 & -68.7 & 0.3 & 0.4 & 0.4 \\
\hline Broker-dealers & 4.9 & 10.2 & 8.1 & 7.9 & 7.9 & 6.0 & 7.7 & 6.8 & 6.6 & -8.0 & 2.0 & 2.1 & 2.1 \\
\hline Monetary authority & 55.3 & 57.4 & 54.8 & 35.3 & 32.9 & 36.7 & - & - & & -4.6 & 2.8 & 2.9 & 3.7 \\
\hline
\end{tabular}

1. Federal funds and security repurchase agreements.

Note: Based on period averages.

Source: Board of Governors of the Federal Reserve System, Financial Accounts of the United States.

16. The largest REITs sold $\$ 30$ billion of MBS within a single week (IMF, 2013).

17. Simulations are based on the National Institute Global Econometric Model (NiGEM) of the UK National Institute of Economic and Social Research. 
ECO/WKP(2014)12

Table 3. Gross trade and financial exposures to the United States

\begin{tabular}{|c|c|c|c|c|c|c|c|}
\hline & \multicolumn{2}{|c|}{ Exports to the United States } & \multicolumn{2}{|c|}{ US equity investments } & \multirow{3}{*}{$\begin{array}{l}\text { US debt } \\
\text { investments } \\
\% \text { of GDP } \\
\text { in receiving country } \\
2012\end{array}$} & \multicolumn{2}{|c|}{ US banks foreign claims } \\
\hline & $\begin{array}{r}\% \text { of total exports } \\
\text { in exporting }\end{array}$ & $\begin{array}{l}\% \text { of GDP } \\
\text { ntry }\end{array}$ & $\%$ of GDP & $\begin{array}{l}\% \text { of market } \\
\text { capitalisation }^{1}\end{array}$ & & $\%$ of GDP & $\begin{array}{c}\% \text { of banks' total } \\
\text { assets }\end{array}$ \\
\hline & 2009 & 2009 & 2012 & 2012 & & $2013 Q 3$ & 2012Q4 \\
\hline Australia & 6.5 & 1.3 & 9.5 & 11.4 & 13.2 & 7.1 & 3.7 \\
\hline Austria & 6.7 & 2.9 & 2.2 & 8.3 & 1.4 & 3.4 & 1.1 \\
\hline Belgium & 7.2 & 3.9 & 8.0 & 12.9 & 1.4 & 3.6 & 1.3 \\
\hline Canada & 66.1 & 17.6 & 20.6 & 18.6 & 23.7 & 6.7 & 3.5 \\
\hline Chile & 12.9 & 4.5 & 5.2 & 4.5 & 5.2 & 3.8 & 4.3 \\
\hline Czech Republic & 2.6 & 1.5 & 1.8 & 9.4 & 0.5 & 2.2 & 2.2 \\
\hline Denmark & 10.0 & 4.2 & 13.7 & 19.3 & 1.9 & 4.6 & 1.9 \\
\hline Estonia & 7.2 & 4.4 & 0.5 & 4.3 & 0.2 & 0.2 & 0.1 \\
\hline Finland & 7.1 & 2.6 & 8.2 & 12.8 & 2.6 & 3.9 & 1.9 \\
\hline France & 8.3 & 1.8 & 9.8 & 14.1 & 4.5 & 8.8 & 2.3 \\
\hline Germany & 8.5 & 3.0 & 6.7 & 15.4 & 3.0 & 5.2 & 1.8 \\
\hline Greece & 11.6 & 2.2 & 1.5 & 8.1 & 0.4 & 4.8 & 0.8 \\
\hline Hungary & 3.9 & 2.7 & 2.0 & 12.1 & 8.4 & 4.8 & 3.8 \\
\hline Iceland & 13.1 & 6.7 & 1.3 & 6.4 & 14.1 & 3.8 & na \\
\hline Ireland & 15.8 & 13.8 & 63.5 & 61.9 & 22.3 & 22.7 & 3.3 \\
\hline Israel & 33.3 & 10.5 & 14.5 & 25.1 & 7.5 & 1.7 & 1.2 \\
\hline Italy & 7.9 & 1.9 & 2.7 & 11.3 & 2.8 & 2.3 & 1.2 \\
\hline Japan & 16.6 & 2.0 & 7.2 & 11.6 & 1.6 & 6.9 & 3.5 \\
\hline Korea & 12.1 & 5.8 & 12.5 & 12.0 & 3.0 & 6.7 & 5.5 \\
\hline Luxembourg & 7.7 & 12.3 & 56.9 & 44.6 & 133.1 & 62.1 & 3.7 \\
\hline Mexico & 71.8 & 18.6 & 6.5 & 14.6 & 6.8 & 9.0 & 24.9 \\
\hline Netherlands & 5.7 & 2.6 & 18.9 & 22.4 & 18.2 & 12.8 & 3.3 \\
\hline New Zealand & 11.6 & 3.1 & 2.3 & 4.8 & 8.3 & 2.9 & na \\
\hline Norway & 10.0 & 4.0 & 4.9 & 9.7 & 9.8 & 2.7 & 1.6 \\
\hline Poland & 2.6 & 1.0 & 2.1 & 5.7 & 4.8 & 3.1 & 3.4 \\
\hline Portugal & 5.3 & 1.4 & 2.1 & 6.9 & 0.9 & 2.2 & 0.7 \\
\hline Slovak Republic & 2.5 & 1.7 & na & na & 0.7 & 0.7 & 0.7 \\
\hline Slovenia & 4.0 & 2.2 & 0.4 & 2.5 & 2.6 & 1.3 & 1.9 \\
\hline Spain & 6.1 & 1.3 & 4.8 & 6.4 & 2.7 & 3.8 & 1.0 \\
\hline Sweden & 8.5 & 3.8 & 12.6 & 11.8 & 10.5 & 4.9 & 1.5 \\
\hline Switzerland & 11.0 & 5.3 & 51.0 & 29.9 & 1.8 & 9.0 & 2.6 \\
\hline Turkey & 8.7 & 1.9 & 3.9 & 10.0 & 2.4 & 3.4 & 3.4 \\
\hline United Kingdom & 16.3 & 4.1 & 30.6 & 25.1 & 14.9 & 22.1 & 6.1 \\
\hline Argentina & 7.6 & 1.6 & 0.3 & 4.7 & 1.2 & 1.2 & 4.4 \\
\hline Brazil & 12.7 & 1.4 & 6.6 & 12.2 & 2.9 & 4.3 & 5.8 \\
\hline China & 22.6 & 5.8 & 1.5 & 3.2 & 0.0 & 0.9 & 0.5 \\
\hline India & 14.1 & 2.9 & 4.1 & 6.0 & 0.2 & 3.4 & 5.2 \\
\hline Indonesia & 11.0 & 2.5 & 3.4 & 7.6 & 1.7 & 1.4 & 3.8 \\
\hline Russian Federation & 7.5 & 2.0 & 2.7 & 6.3 & 0.6 & 1.8 & 2.5 \\
\hline South Africa & 10.0 & 2.6 & 18.5 & 11.6 & 3.8 & 2.8 & 2.7 \\
\hline
\end{tabular}

1. Market capitalisation data (from the World Bank, WDI) include listed companies but exclude investment companies, mutual funds, or other collective investment vehicles. In contrast, equity investments data (from TIC) cover listed, non-listed companies and fund shares. For Ireland, the market capitalisation is data from Irish Stock Exchange.

Note: Light grey shading indicates countries whose exposure indicator is between the top quartile and the top decile of the cross-country distribution, while dark grey shading indicates countries whose exposure indicator is in the top decile.

Source: OECD calculations based on data from the US Department of Treasury, Treasury International Capital System; BIS consolidated banking statistics; WDI, World Bank; OECD-WTO Trade in Value Added databases and Irish Stock Exchange. 
Figure 7. GDP effects of a financial shock in the United States

\section{A. Constant exchange rates}

$\%$

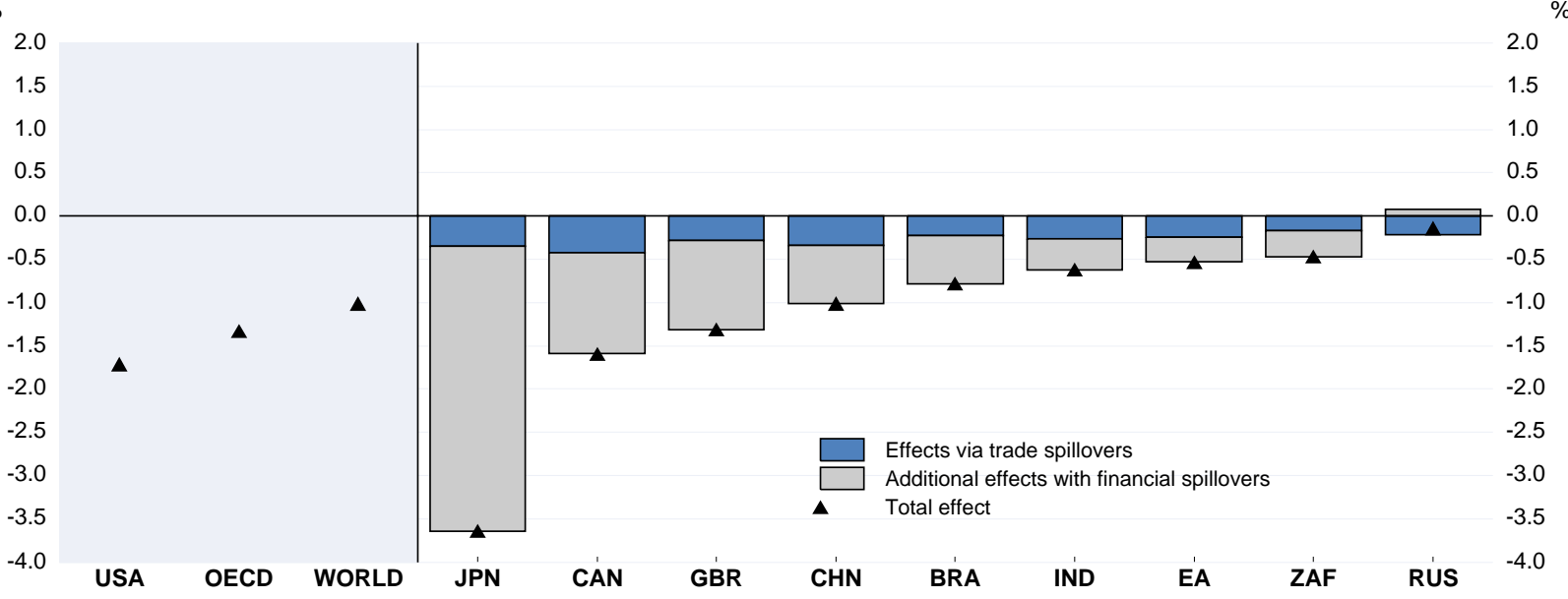

B. $10 \%$ nominal depreciation vis-à-vis the US dollar

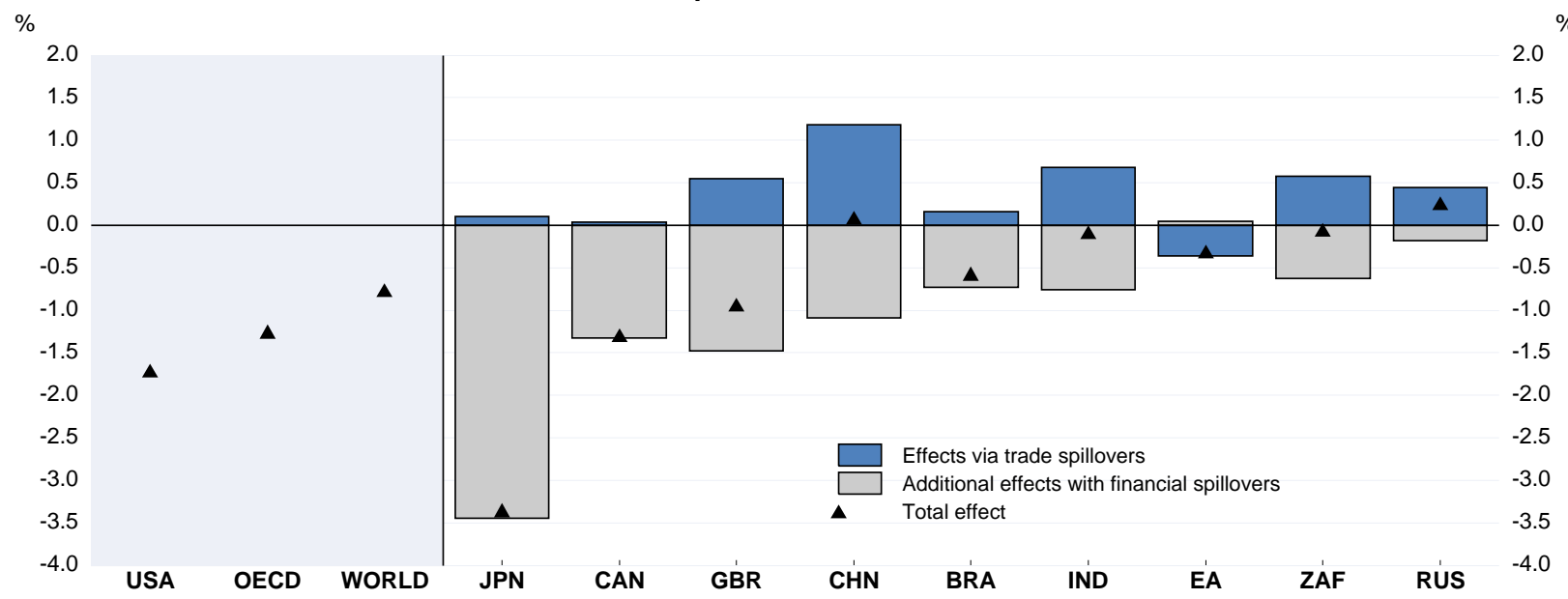

Note: The financial shock in the United States assumes a 200-basis point increase in the US long-term interest rates and endogenous equity price reaction, while in other countries interest rates and equity prices are fixed. The total effect assumes that in other countries long-term interest rates and equity prices change by the same amount as in the United States. The very large effect for Japan stems from a high sensitivity of business investment to long-term interest rates in the NiGEM.

Source: OECD calculations based on NiGEM. 


\section{Risks of negative international spillovers}

The impact of the tightening of monetary conditions in the United States on other countries will depend importantly on its impact on the US economy and the intensity of financial and trade linkages (Table 3) as well as policy reactions in countries affected by spillovers (see next section). While the focus in this section is on the spillovers from the United States, similar developments could be experienced during the exit in other main OECD economies. For the United Kingdom, global ramifications would likely be limited given its relatively small weight in the world economy, but European neighbours would be noticeably affected via trade and financial channels. In contrast, more sizeable effects could be expected in the case of the euro area and Japan, reflecting their respective weights in the global economy, though moves towards exit in these economies are not likely before 2016 .

\section{Trade spillovers}

Direct and indirect spillovers through trade are likely to be moderate. They will vary across countries, depending on the strength of trade links with the United States, and be larger for the main trading partners of the United States, including Canada, Chile, China, Iceland, Israel, Ireland and Mexico (Table 3). According to macro-model simulations for selected OECD and EMEs, in the absence of financial international spillovers, ${ }^{18}$ even a 200 -basis point increase in 10 -year US government bond yields during one year, resulting in a decline in the US GDP by $1 \frac{1}{2}$ per cent compared with the baseline, would reduce GDP growth in the analysed countries by less than 0.4 percentage point (Figure 7). The trade spillovers would be even smaller if the dollar were to appreciate in response to widening interest rate differentials. Assuming a 10\% depreciation of the currencies of the countries analysed against the US dollar could even result in higher GDP growth in some economies.

\section{Financial spillovers}

Given the importance of the United States in the world economy, reflecting inter alia the reserve currency status of the US dollar, any financial turbulences related to changes in US monetary policy would be bound to spill over to other economies as experienced most recently in mid-2013 and on several other occasions in the past.

\section{Spillovers via security markets}

Rapidly rising interest rates cause financial losses on securities and may create liquidity problems for leveraged investors. Substantial losses on US bond holdings could encourage US investors to reduce their positions abroad. Such divesting dynamics are assessed to have been one of the drivers behind the 1994 bond sell-off (Borio and McCauley, 1995). This effect is potentially large given that the US private financial sector has non-negligible holdings of both US and foreign bonds (Table 2). ${ }^{19}$ Developments in mid-2013 suggest that such a channel was at work as US financial institutions sold foreign bonds in the second quarter of 2013. Judging by aggregate data for all US investors, this channel operated vis-à-vis EMEs but not advanced OECD countries, as US residents sold foreign bonds in EMEs but continued to acquire them in the advanced OECD countries (Figure 8). If the liquidity channel in bond markets were to be important, countries where US holdings of securities are large could be particularly affected, including Hungary - among EMEs - and Australia, Canada, Iceland, Ireland, Luxembourg, Norway, Sweden and the United Kingdom - among advanced economies (Table 3).

18. Simulations assume unchanged long and short-term interest rates, equity prices and exchange rates in the analysed US trade partners.

19. US flow of funds data do not, however, allow to distinguish between holdings of US corporate bonds and of foreign bonds. 
Figure 8. Net acquisition of foreign assets by US residents 3-month moving average, billion USD
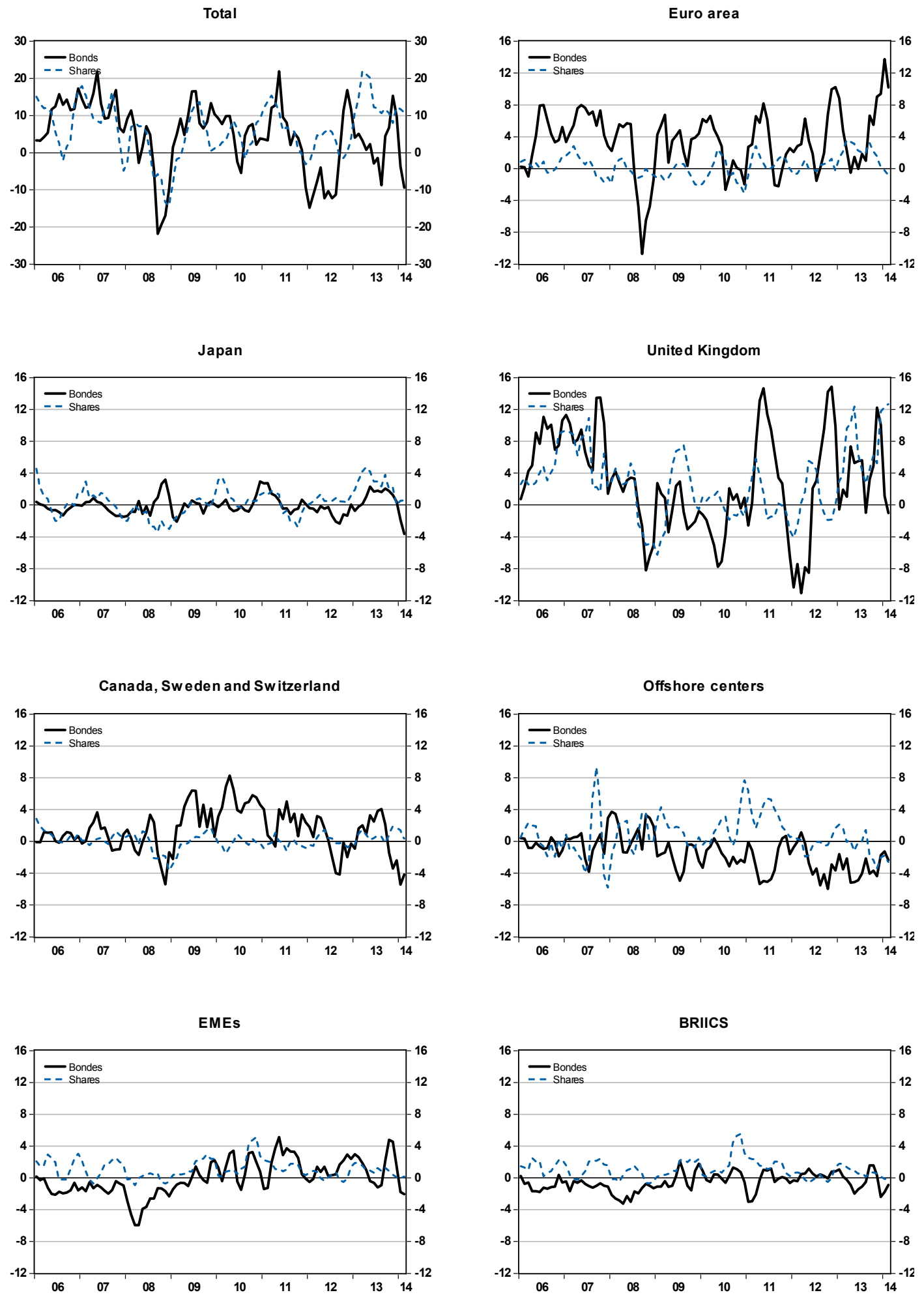

Note: EMEs include Chile, Hungary, Mexico, Poland, Turkey and BRIICS (Brazil, Russia, India, Indonesia, China and South Africa), Last observation: February 2014.

Source: US Department of Treasury International Capital System. 
Liquidity-driven bond spillovers could be amplified by non-US investors, if in need of liquidity in the wake of losses on US Treasuries, selling domestic bonds or bonds of third countries. Incentives to dispose domestic bonds would be reduced if domestic currencies depreciate against the US dollar, partially offsetting the losses in domestic currency terms. Data limitations prevent assessing the scope for this effect in general and its role during the latest episode of a rapid increase in the US long-term interest rates. In mid-2013, foreign investors indeed fled the US Treasury bond market (Figure 9), but it is not clear whether the unwinding of the US bond positions made them liquidate their domestic or foreign non-US positions. Outflows of foreign investors from the Treasury bond market were initially driven primarily by private investors, but official investors increased sales after mid-2013. ${ }^{20}$

The shock to bond prices could be amplified via the banking sector both in the United States and in other countries if it has negative impacts on bank balance sheets via realised and unrealised losses and prompts tightening of credit conditions. Such risks are particularly high in Japan, given much higher holdings of government debt on bank balance sheets, where the impact of a 1-percentage point parallel upward shift of the yield curve could be sizeable (Bank of Japan, 2013; and Box 1.5 in OECD, 2013b) ${ }^{21}$ In most euro area countries and the United Kingdom, the estimated impact would be much smaller, though the effects could be more pronounced with a larger increase in bond yields as banks are generally less well capitalised. ${ }^{22}$ In addition, when banks fund themselves via collateralised borrowing, a decline in prices could lower the value of collateral and trigger margin calls. These adverse developments could be amplified by potential losses on other assets, in particular loans if growth were to slow down significantly (see below). Thus, a material deterioration in balance sheets could prompt banks to reduce their crossborder claims. In case of the United States, the transmission of the shock via the banking sector to most countries is not likely to be large since foreign claims of US banks, based on the BIS consolidated data, are small in relation to debtor country's GDP and total banks' assets, with the exception of - among others Brazil, Ireland, Luxembourg, Mexico, the Netherlands, South Korea, Switzerland and the United Kingdom (Table 3). ${ }^{23}$

20. Foreign investors hold around $45 \%$ of outstanding Treasury bonds and federal agencies securities. China and Japan account each for over $20 \%$ of the Treasury holdings by non-residents, while Caribbean banking centres and oil exporting countries together for nearly $10 \%$. Foreign investors are dominated by official institutions (primarily central banks and government pension funds), which hold around three-quarters of total Treasury bonds and half of agency bonds held by non-residents. The opposite is true for the corporate bond market, where private non-resident investors dominate over official institutions, accounting for nearly $95 \%$ of total holdings by non-residents.

21. The BoJ estimates that a 1-percentage point parallel upward shift of the yield curve would lead to unrealised losses of 6 trillion yen (nearly 14\% of Tier 1 capital of large and regional banks), while a 300-basis point shock would inflict losses of 15.3 trillion yen (around 35\% of Tier 1 capital).

22. ECB (2013) notes that banks should be less affected by the bond price shock than institutional investors, like insurers, pension and investment funds, given their smaller exposure to debt instruments.

23. Around half of this exposure comes via the ownership of local subsidiaries and one-fourth is in the form of claims on banks. BIS data on foreign claims include cross-border claims, and local claims of foreign affiliates in foreign and local currencies. Sectoral data do not distinguish between cross-border claims and claims of foreign affiliates. 
Figure 9. Net acquisition of US assets by non-residents

3-month moving average, billion USD

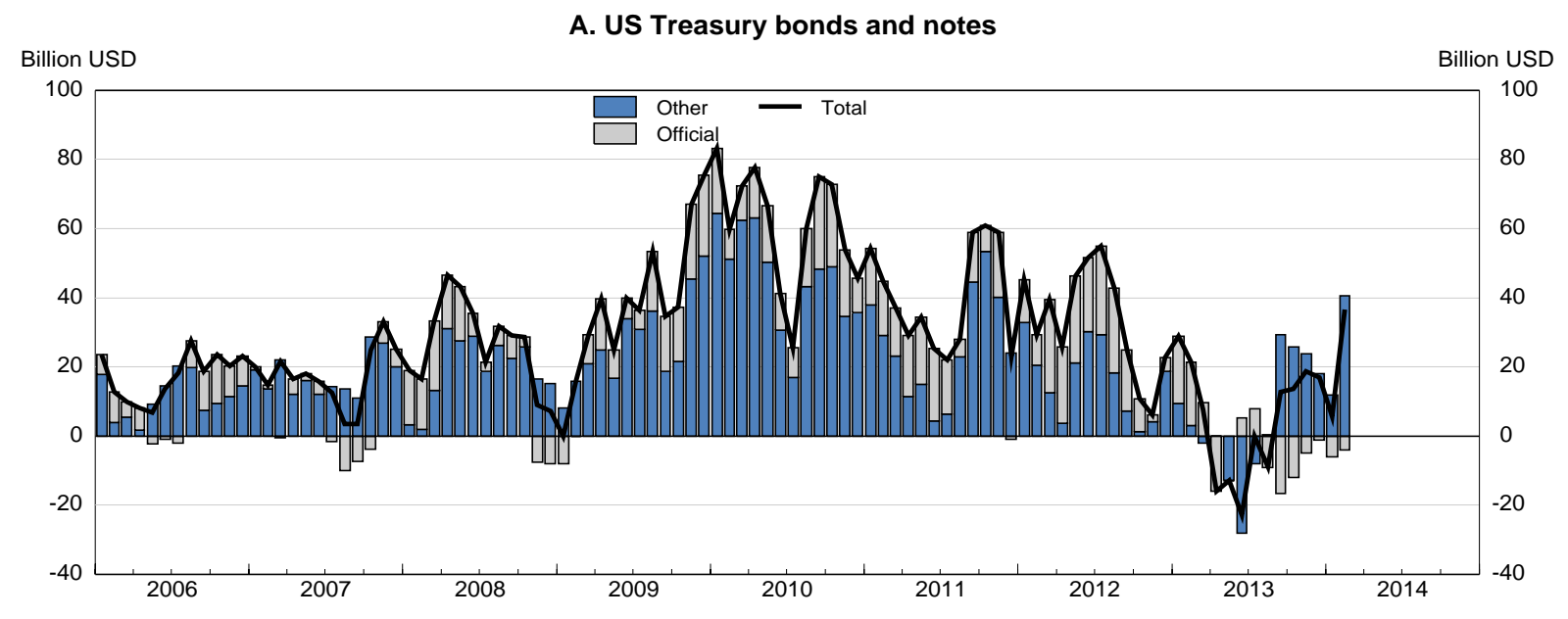

B. US sovereign securities

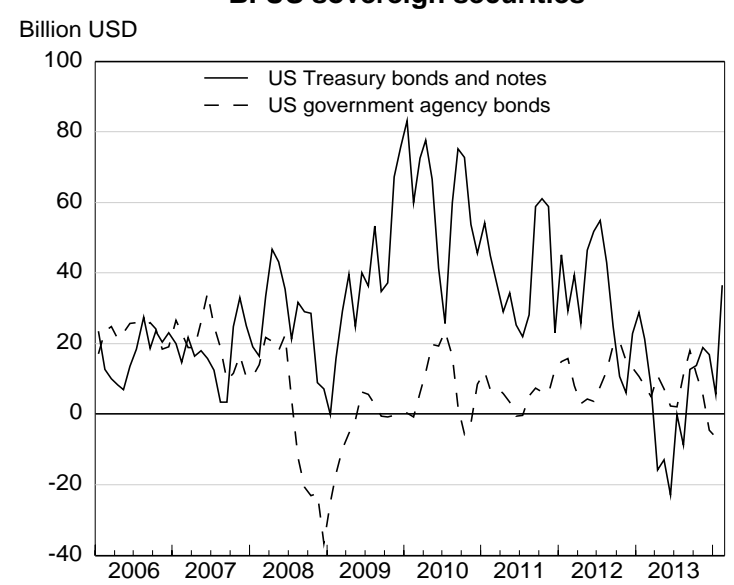

C. US corporate securities

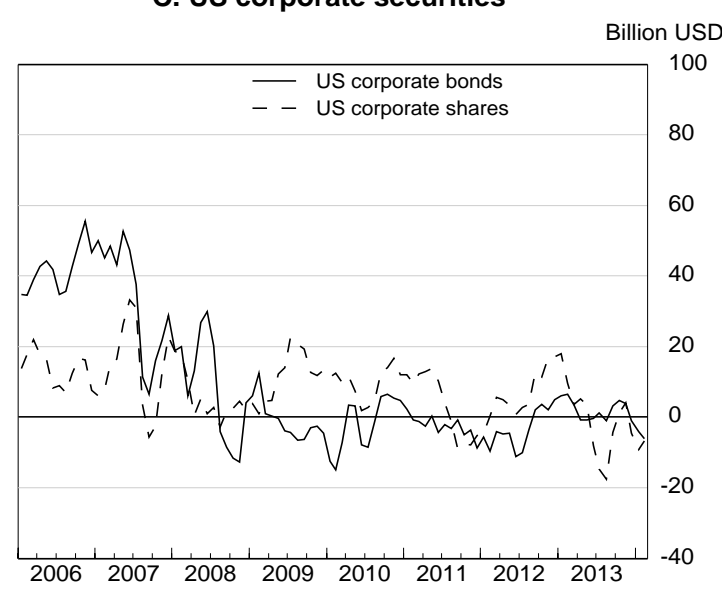

Note: Last observation: February 2014.

Source: US Department of Treasury International Capital System.

Negative shocks could also spread via stock markets due to various market mechanisms discussed in Appendix 2. At the beginning of the mid-2013 bond sell-off in the United States, stock markets declined significantly across the globe. US residents kept on acquiring foreign stocks both in advanced OECD economies and EMEs but in smaller amounts than in the preceding months, while non-US investors sold US corporate stocks (Figures 8 and 9). If the transmission of equity shocks were to be driven by US investors, then countries with an important presence of US investors in stock markets could be affected more. Such countries include among EMEs: China, India and Mexico, and among advanced economies: Canada, Denmark, Germany, Israel, Ireland, Luxembourg, South Korea, Switzerland and the United Kingdom (Table 3). ${ }^{24}$

24. Likely reflecting the impact of many other factors, there was only very weak positive correlation between the equity market exposure to the United States and the maximum decline in equity prices around mid-2013. 


\section{Herd behaviour}

Financial market spillovers can be fuelled by herd behaviour amid increasing uncertainty, aggravating crisis dynamics (Appendix 2). The muted impact of the mid-2013 drop in bond prices on uncertainty in the United States, as measured by implied volatility of the US equity prices (Figure 6), does not, however, exclude the possibility of a sudden increase in uncertainty in the future. A sell-off in financial markets due to herd behaviour is not likely to be long-lasting in countries with strong fundamentals, as was the case in 2008 for EMEs (Ollivaud et al., 2014) and early 2014 (see below). However, it may serve as a wake-up call for investors and trigger financial instability in countries with underlying vulnerabilities. Such risks exist in the euro area, where vulnerability still persists, related to lingering problems in the banking sector and still unfinished institutional reforms, including the lack of a fully-fledged banking union. Similarly, Japan faces daunting fiscal challenges, where debt dynamics are very sensitive to bond yields, making public finances vulnerable to sudden shifts in market sentiment. Some EMEs are also susceptible to wakeup calls given surfacing vulnerabilities (see below and Ollivaud et al., 2014).

\section{Exchange rate spillovers}

Spillovers from the United States could add to financial stress in other countries if they were to lead to sizeable exchange rate depreciation in the presence of large liabilities denominated in foreign currencies. Such risks seem to be more relevant for EMEs since foreign currency denominated liabilities have been on the rise in some EMEs (see below) and exchange rates in EMEs tend to be more volatile than in advanced OECD countries during turbulent times. During the mid-2013 bond sell-off and early 2014 turbulence episode, EMEs' currencies depreciated generally by more than in the advanced OECD economies. Beyond financial stability implications, exchange rate depreciations could have implications for inflation dynamics, possibly complicating the conduct of monetary policy, but as discussed above may partly cushion the shock on activity by boosting net exports (Figure 7).

\section{Specific considerations for EMEs}

The spillovers via bond and equity markets can also be more virulent in EMEs than in advanced economies as their bond and equity markets are generally less liquid and thus more sensitive to outflows by foreign investors, ${ }^{25}$ in spite of an increase in the market depth of domestic government bond markets in EMEs in the past decade (Mehrotra et al., 2012). For instance, bid-ask spreads on government bonds in EMEs are in general larger than in advanced economies, and, with the exception of Mexico and South Africa, the turnover of these bonds remains low relative to total amounts outstanding (Figure 10). Also, although liquidity in equity markets has increased in a number of EMEs in the past decade, turnover rates in many EMEs, with the exception of Turkey and China, remain well below those observed in most advanced economies (Figure 10).

25. Though, highly liquid markets could be more vulnerable to contagion (Appendix 2). Eichengreen and Gupta (2013) show that during the mid-2013 episode, EMEs with large and liquid markets experienced more financial stress as measured by an index of weighted changes in exchange rates, foreign exchange reserves and equity prices. 
Figure 10. Indicators of market liquidity

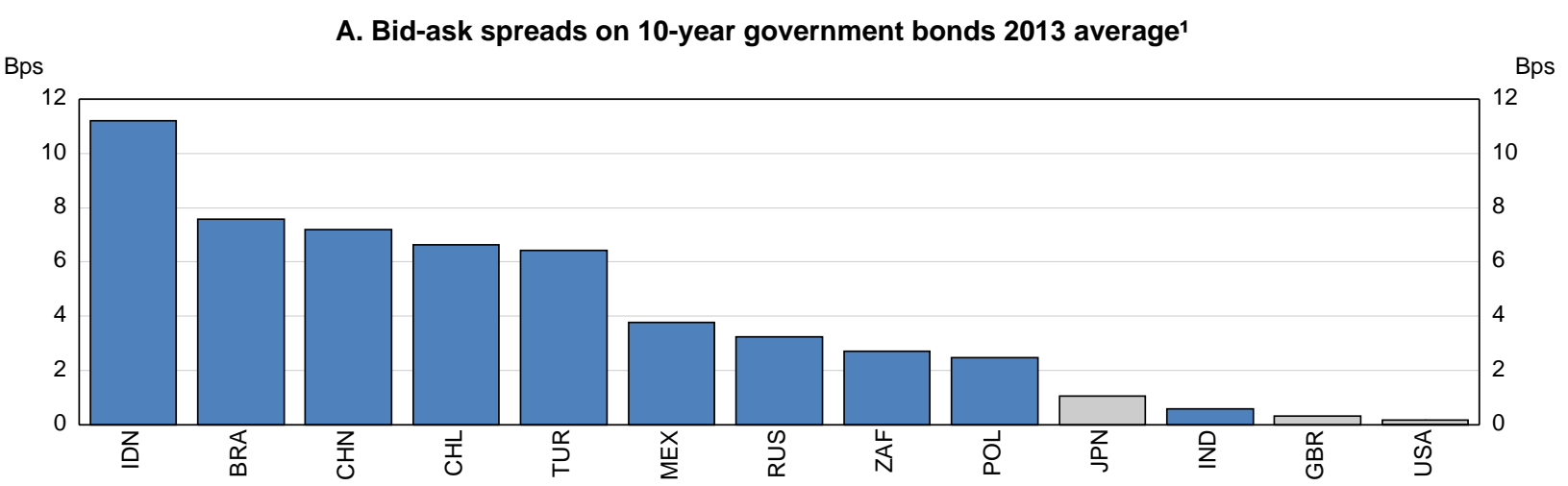

B. Ratio of government bond market turnover to total capitalisation, 2010

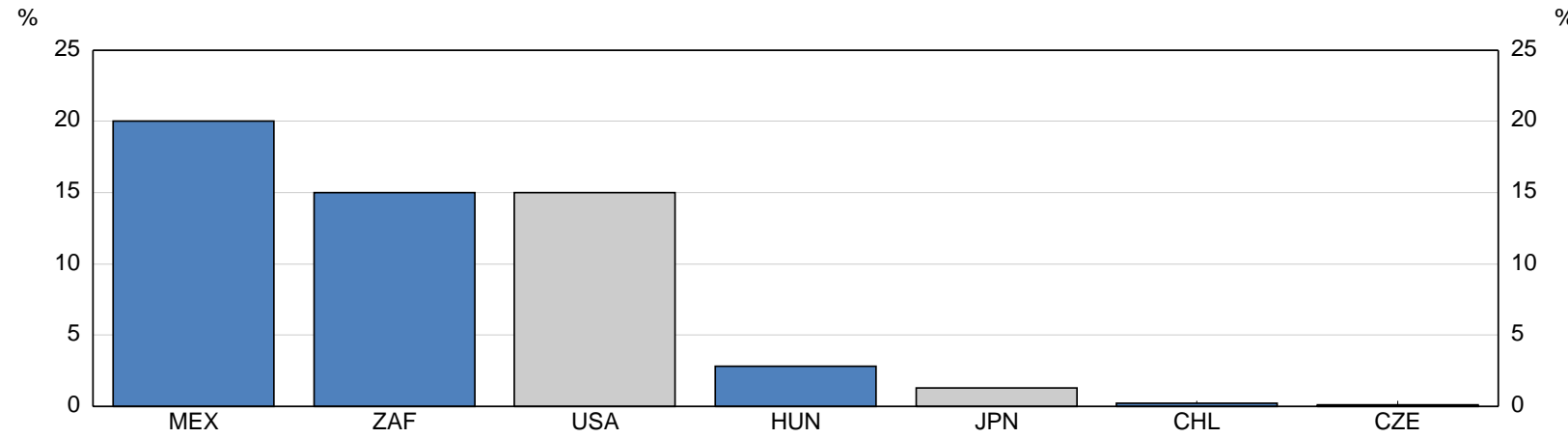

C. Ratio of equity market turnover to total capitalisation, 2012

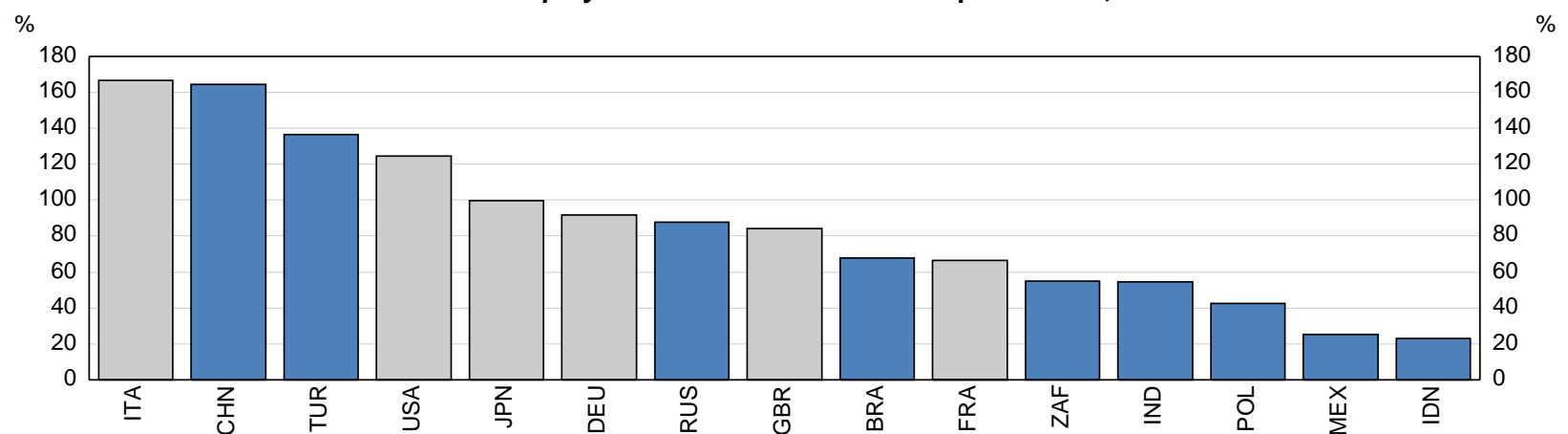

1. For Brazil, the bid-ask spread is computed for the generic 9-year government bond.

Note: Darker bars refer to EMEs.

Source: Bloomberg; central bank responses to a BIS questionnaire (see Mehrotra et al., 2012); and World Bank Development Indicators.

An increased recognition of weakening fundamentals was already evident in several EMEs in 2013, amid emerging signs of financial vulnerabilities related to the banking system and external financing (Ollivaud et al., 2014). Such signs included rapid credit growth, the increasing incidence of nonperforming loans and lower liquidity coverage ratios as well as the increased dependence of some external deficit economies on portfolio inflows, the higher share of debt in total foreign liabilities and the increased reliance on short-term loans from foreign banks. Another concern was the sharp rise in dollar-denominated debt issued by companies in several EMEs, in particular through offshore financial centres (BIS, 2013). 
This should be seen in the context of increasing bond issuance, helped by higher demand from foreign investors due to low returns in advanced countries, and some deterioration in the quality of new issuances, even if investment-grade firms are estimated to account for most of this rise (IMF, 2013).

Until early 2014, financial market turbulence did not, however, lead to major financial instability and asset price corrections during the episode of renewed turbulence in early 2014 were smaller and more differentiated than in mid-2013 (Figure 11). This partly stemmed from the fact that in several EMEs shocks originated domestically due to increasing geopolitical and economic uncertainty rather than from the United States. However, this also reflected the recently improving external imbalances (India and Indonesia), higher policy rates (Brazil, India and Indonesia) and an improved monetary policy framework (India). Moreover, despite some vulnerabilities, EMEs are generally better prepared to cope with capital outflows than in the late 1990s and early 2000s, reflecting flexible exchange regimes, larger foreign currency reserves, lower foreign currency debt, better capitalised financial institutions and more matured policy institutions.

Figure 11. The financial turmoil in EMEs in early 2014 was less acute than in mid-2013 In per cent

\section{A. Equity prices ${ }^{1}$}

$\%$

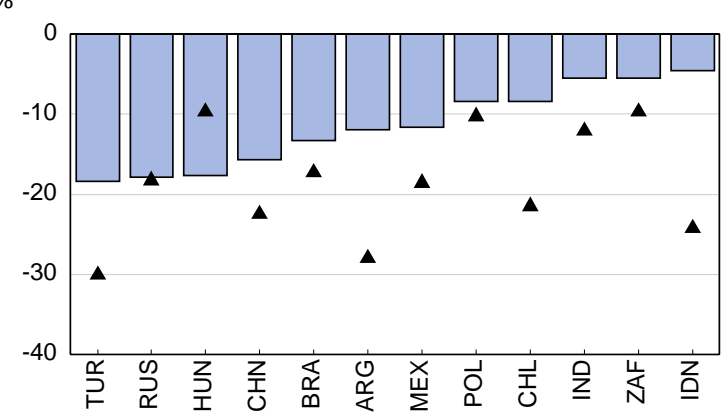

B. Nominal effective exchange rates $^{2}$

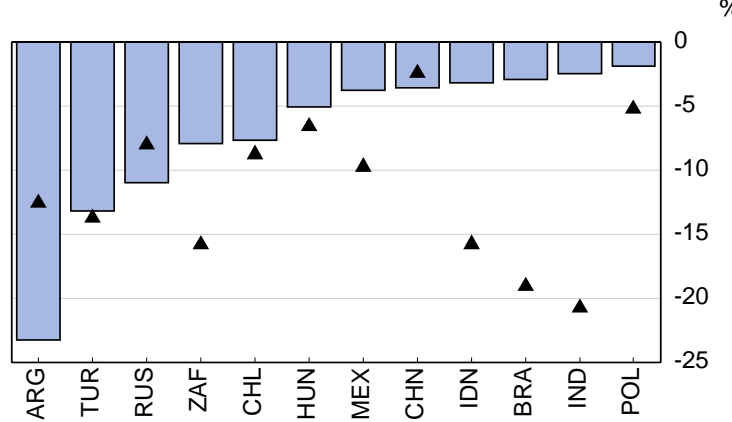

\section{Long-term government bond yields ${ }^{3}$}

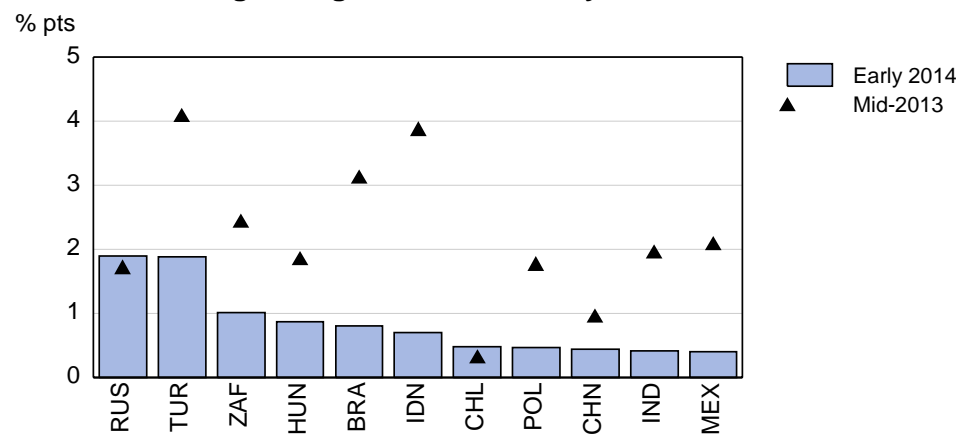

1. Percentage change from peak to through between 2013Q2 and 2013Q3 for the mid-2013 period, and between December 2013 and end-March 2014 for the early 2014 period. Equity prices are expressed in domestic currency.

2. Percentage change from peak to through between 2013 Q2 and 2013Q3 for the mid-2013 period, and between December 2013 and end-March 2014 for the early 2014 period. A decline in the nominal effective exchange rate implies its depreciation.

3. Percentage point change from through to peak between 2013Q2 and 2013Q3 for the mid-2013 period, and between December 2013 and end-March 2013 for the early 2014 period.

Source: OECD STEP 95 database; and Datastream. 
China was not affected by the bond sell-off in mid-2013, partly reflecting restrictions on capital flows, but negative spillovers from the United States cannot be excluded in the future. Currency mismatches have been on the rise, with foreign currency loans having increased by $35 \%$ over the year to the first quarter of 2013 (i.e. more than twice the rise of renminbi loans), while outstanding foreign currency bonds have more than doubled between 2010 and the first quarter of 2013 (He and McCauley, 2013). China could also act as a shock amplifier, if home grown financial sector instability were to coincide with the normalisation of monetary policies in the OECD advanced economies, given its potential to affect global growth and investors' sentiment, especially in other EMEs (Appendix 3). Vulnerabilities of the Chinese financial sector may have indeed increased, relating to rapid growth in domestic credit and the expansion of the shadow banking system, in particular of securities and trust companies, the corporate bond market and wealth management products. These developments raise concerns about the quality of underwriting standards, pricing of risks and liquidity risks due to maturity mismatches. While banks are relatively wellcapitalised, non-performing loans low and loss provisions high (PBoC, 2013), ${ }^{26}$ they remain vulnerable to problems in the shadow banking sector, a worsening in the financial performance of the corporate sector and local governments, and an eventual decline in house prices after their rapid increase in recent years.

\section{Quantification of financial spillover effects}

Protracted and large spillovers from the United States could have sizeable global ramifications in the current environment, including feedbacks to the United States, though such feedbacks via EMEs would not likely be large given limited direct exposures of US investors to EMEs (Ollivaud et al., 2014). Macromodel simulations suggest that a stylised shock of 200-basis point increase in 10-year government bond yields combined with a $25 \%$ decline in equity prices in the United States and several other large economies during one year would lower OECD GDP growth by more than 1 percentage point, with particularly large effects in Canada, Japan and the United Kingdom (Figure 7). ${ }^{27}$ Were such a shock to materialise now, in addition to the trade effects, still weak OECD economic growth could be halved, fuelling further negative feedback loops between financial conditions and growth.

\section{Policy implications}

In the main OECD areas, monetary authorities will be faced with the challenge of normalising monetary policies and ensuring financial market stability. Communication could help minimise volatility but in practice controlling market expectations could prove difficult. Designing announcements to have gradual effect on expectations is not easy.

As discussed above, the Fed is likely to face these challenges before the monetary authorities in the other main OECD areas. In the still fragile economic environment, the Fed will have to take into account spillovers, at least to the extent they have feedback to the US economy. With the wind-down of asset purchases appropriate in 2014 and interest rate increases required from early 2015 on the basis of the November 2013 OECD projections, it may be desirable that the Fed provide more clarity about the principles of the unwinding of QE policies (in terms of the pace and composition) and about policy rates once the tightening cycle starts, ${ }^{28}$ bearing in mind the challenges associated with the necessarily conditional character of any communicated guidance (OECD, 2013b).

26. The Tier 1 capital adequacy ratio is around $10 \%$ and the on-balance-sheet non-performing loan ratio in commercial banks is around $1 \%$, with loss provisions nearly three times higher than NPLs.

27. The very large effect for Japan stems from a high sensitivity of business investment to long-term interest rates in the NiGEM macroeconomic model. The model simulations account for negative feedback effects from the affected countries to the United States, which, however, turn out to be very small.

28. English et al. (2013) argue that revealing the Fed's reaction function during the tightening cycle could help lower market participants' expectations about increases in policy rates and thus stimulate the economy. 


\section{Policies to improve resilience to financial shocks}

With their limited control of financial market reactions and international spillovers, countries exiting from extraordinary monetary policy accommodation and countries exposed to international spillovers should address current vulnerabilities to improve their resilience to interest rate shocks. This calls for better regulation and supervision to ensure sufficient capital and liquidity buffers of banks and other financial institutions in the United States and elsewhere. Micro and macro-prudential policies could be useful for preventing a build-up in financial vulnerabilities in specific markets in the current environment of still low interest rate and abundant liquidity. Macro-prudential measures could be attractive for advanced OECD countries where such policy instruments have been little used so far (Box 1.5 in OECD, 2013a).

The on-going strengthening of banking regulation under Basel III and the implementation of recent proposals to tighten requirements for large financial institutions regarding liquidity and leverage ratios in the United States should help weather the normalisation of monetary policies. In the euro area, in view of weak, even if improving, banks' balance sheets (ECB, 2013), the 2014 asset quality review and bank stress tests need to identify bank weaknesses and corresponding recapitalisation needs and be followed by a swift bank resolution or recapitalisation. Testing the resilience of banks in several EMEs that experienced rapid credit growth in recent years would also be desirable as lending standards could have been compromised.

Structural reforms, in particular to boost potential growth and ensure fiscal sustainability, which improve general macroeconomic fundamentals and investors' confidence, should strengthen resilience to shocks. Reducing regulatory burdens on foreign direct investment, easing strict product market regulation and removing tax incentives for debt over equity financing could promote a safer structure of foreign liabilities and reduce the risk of volatile capital flows (Ahrend and Goujard, 2012).

The risk of disruptive fire sales should be addressed. Possible measures to prevent a build-up of such a risk include a modification of liquidity regulation for broker-dealers; universal margin requirements in the form of minimum haircuts on collateralised short-term lending that could involve cyclical surcharges; or a higher minimum leverage ratio (Stein, 2013). Options to implement a resolution authority to manage an orderly and paced unwinding of repo collateral during turbulent times could be also considered (IMF, 2013). A provision of emergency liquidity assistance for shadow banking institutions could be envisaged, though this would require a far stricter oversight of these institutions, which would be desirable in any case given their structural vulnerabilities, in particular MMFs and agency REITs.

Establishing international currency swap lines could be useful to limit short-lived foreign currency liquidity problems and to mitigate their effects on economic conditions. The conversion of temporary bilateral liquidity swap arrangements among six central banks to standing arrangements in October 2013 is a welcome development. ${ }^{29}$ Similar agreements could be considered between EMEs and advanced economies. The IMF flexible credit line could provide an additional support to countries with strong fundamentals and policy track records and faced with potential or actual balance of payments stress. ${ }^{30}$

29. The arrangement was agreed on 31 October between the Bank of Canada, the Bank of England, the Bank of Japan, the European Central Bank, the Federal Reserve and the Swiss National Bank.

30. Colombia, Mexico and Poland have currently access to the IMF flexible credit line. 


\section{Policies to counteract financial shocks}

Macroeconomic policies could be adjusted to limit undesirable effects of spillovers from the tightening of monetary policy in the United States, depending on the nature of the shock, initial conditions as well as scope for policy action:

- The monetary policy response would vary with inflation and exchange rate developments. In countries where spillovers result in large exchange rate depreciation and capital outflows, the textbook macroeconomic policy response would be to tighten policy rates to limit capital outflows, while supporting demand through fiscal policy. The actual policy response would, however, depend importantly on each country's specific conditions. The intensity of the monetary policy response should depend on prevailing inflation and the credibility of the central bank. When inflation is high or inflation expectations poorly anchored, monetary policy should be tightened more, even if growth is weak. Several EMEs, faced with such conditions, have already raised policy rates.

- The intensity of the fiscal policy responses will also depend on the available leeway, so that it does not undermine investors' confidence. Advanced OECD economies do not have much room for fiscal adjustment beyond automatic stabilisers, given generally high deficits and debt levels. In contrast, some EMEs would have more policy space, though foreign investors may have reduced their tolerance for fiscal imbalances and in some of them the scope to provide fiscal support has diminished since the onset of the global recession because of the run-up in public debt (China) and high budget deficits (India).

- While exchange rates should be allowed to adjust flexibly to changing fundamentals, transparent and temporary interventions may play some role in reducing short-term currency volatility and financial instability. While considering such measures, their possible limited effectiveness should be taken into account. When faced with capital outflows, introducing capital outflow controls is likely to be inefficient and may even backfire. 


\section{BIBLIOGRAPHY}

Adrian, T., R. Crump, and E. Moench (2013a), "Do Treasury Term Premia Rise around Monetary Tightenings?", Liberty Street Economics, Federal Reserve Bank of New York.

Adrian, T, M. Fleming, J. Goldberg, M. Lewis, F. Natalucci, and J. Wu (2013b), "Dealer Balance Sheet Capacity and Market Liquidity during the 2013 Selloff in Fixed-Income Markets", Liberty Street Economics, Federal Reserve Bank of New York.

Ahrend, R. and A. Goujard (2012), "International Capital Mobility and Financial Fragility - Part 3. How Do Structural Policies Affect Financial Crisis Risk?: Evidence from Past Crises Across OECD and Emerging Economies", OECD Economics Department Working Papers, No. 966, OECD Publishing.

Bank of England (2013), Inflation Report, November.

Bank of Japan (2013), Financial System Report, October.

Bauer, M.D. and G.D. Rudebusch (2013), "What Caused the Decline in Long-term Yields?", FRBSF Economic Letter, No. 2013-19, 8 July, Federal Reserve Bank of San Francisco.

Bauer, M.D., G.D. Rudebusch, and J.C. Wu (2014), "Term Premia and Inflation Uncertainty: Empirical Evidence from an International Panel Dataset: Comment", American Economic Review, Vol. 104(1), pp. 323-37.

Bernanke, B.S. (2013), “Communication and Monetary Policy”, Remarks at the National Economists Club Annual Dinner, Herbert Stein Memorial Lecture, Washington, 19 November.

BIS (2013), BIS Quarterly Review, September.

Board of Governors of the Federal Reserve System (2014), Dodd-Frank Act Stress Test 2014: Supervisory Stress Test Methodology and Results, March.

Borio, C. and R. McCauley (1995), “The Anatomy of the Bond Market Turbulence of 1994”, BIS Working Paper, No. 32, Bank for International Settlements.

Bouis, R., $Ł$. Rawdanowicz, J.P. Renne, S. Watanabe, and A.K. Christensen (2013), "The Effectiveness of Monetary Policy since the Onset of the Financial Crisis", OECD Economics Department Working Papers, No. 1081, OECD Publishing.

Cochrane, J.H. (2007), "Commentary on 'Macroeconomic Implications of Changes in the Term Premium", Federal Reserve Bank of St. Louis Review, Vol. 89(4), pp. 271- 82.

ECB (2013), Financial Stability Review, November.

Eichengreen, B. and Gupta, P. (2013), "Tapering Talk: The Impact of Expectations of Reduced Federal Reserve Security Purchases on Emerging Markets", World Bank Working Paper. 
English, W.B., J.D. Lopez-Salido, and R.J. Tetlow (2013), "The Federal Reserve's Framework for Monetary Policy - Recent Changes and New Questions", Finance and Economics Discussion Series Working Papers, No. 2013-76, The Federal Reserve Board.

FSOC (2013), FSOC Annual Report 2013, Financial Stability Oversight Committee.

He, D. and R. McCauley (2013), "Transmitting Global Liquidity to East Asia: Policy Rates, Bond Yields, Currencies and Dollar Credit”, BIS Working Papers, No. 431, Bank for International Settlements.

HM Treasury (2014), Forecasts for the UK economy: A Comparison of Independent Forecasts, No. 322, February.

IMF (2013), Global Financial Stability Report, October.

Mehrotra, A., K. Miyajima, and A. Villar (2012), "Developments of Domestic Government Bond Markets in EMEs and their Implications", BIS Working Paper, No. 67, Bank for International Settlements.

Minegishi, M. and B. Cournède (2010), "Monetary Policy Responses to the Crisis and Exit Strategies", OECD Economics Department Working Papers, No. 753, OECD Publishing.

OECD (2013a), OECD Economic Outlook, Vol. 2013/1, OECD Publishing.

OECD (2013b), OECD Economic Outlook, Vol. 2013/2, OECD Publishing.

Ollivaud, P., E. Rusticelli and C. Schwellnus (2014), "Would a Growth Slowdown in Emerging Markets Spill over to High-Income Countries? A Quantitative Assessment", OECD Economics Department Working Papers, No. 1110, OECD Publishing.

PBoC (2013), China Financial Stability Report, Financial Stability Analysis Group of the People's Bank of China.

Rawdanowicz, Ł., R. Bouis and S. Watanabe (2013), "The Benefits and Costs of Highly Expansionary Monetary Policy”, OECD Economics Department Working Papers, No. 1082, OECD Publishing.

Stein, J.C. (2013), "The Fire-Sales Problem and Securities Financing Transactions", speech at the Federal Reserve Bank of New York Workshop on Fire Sales as a Driver of Systemic Risk in Triparty Repo and other Secured Funding Markets, New York, October 4.

Turner, P. (2013), "Benign Neglect of the Long-Term Interest Rate", BIS Working Papers, No. 403, Bank for International Settlements, February. 
ECO/WKP(2014)12

\section{APPENDIX 1. LARGE-SCALE ASSET PURCHASES AND CENTRAL BANK BALANCE SHEETS}

This appendix reviews current policies regarding large-scale asset purchases and liquidity provisions by central banks in the euro area, Japan, the United Kingdom and the United States, and presents stylised projections of their balance sheets, assuming that the asset purchased will be held to maturity.

Over the past five years, central bank balance sheets have expanded massively though in different ways and for different ends. In the near future, they are likely to expand further in the United States and Japan, stay unchanged in the United Kingdom, and continue to shrink in the euro area:

- The BoJ aims to double its holdings of government bonds from 89 trillion yen to 190 trillion yen ( $40 \%$ of GDP) by end-2014, with a view to double the monetary base to 270 trillion yen $(57 \%$ of GDP). The planned asset purchases could be, however, changed depending on prospects for achieving the inflation target.

- The US Fed decided in December 2013, January and March 2014 to reduce each time by $\$ 5$ billion the monthly purchases of agency mortgage-backed securities from initial $\$ 40$ billion to $\$ 25$ billion ( $0.15 \%$ of annual GDP) and of long-term Treasury securities from initial \$45 billion to $\$ 30$ billion. It signalled that, conditional on the sustained improvement in the labour market and inflation moving back towards its target, it would continue reducing asset purchases to cease them entirely towards the end of 2014.

- The BoE finished its latest round of asset purchases in October 2012 and has maintained its stock at $£ 375$ billion (24\% of GDP) since then. It does not intend to reduce the stock of assets purchased before policy interest rate will have been raised.

- In the euro area, purchases of government and covered bonds have been small compared with other central banks ( $€ 250$ billion, $2.7 \%$ of GDP) and extra liquidity has been mainly injected by long-term refinancing operations, in particular two 3-year loans totalling to over $€ 1$ trillion (nearly $11 \%$ of GDP). ${ }^{1}$ Thus, the shrinking of the Eurosystem balance sheet will depend on the repayments of current loans. By early April 2014, €504.7 billion of the three-year loans had been already repaid. The remaining loans will have to be repaid at the latest in early 2015 .

In order to shed light on a possible future evolution of central bank balance sheets, stylised projections have been made, assuming that the securities purchased will be held to maturity (Figure A1.1). Government bonds are categorised into several broad maturity tranches and they are assumed to be reduced until their share in GDP reaches the pre-crisis level. The amount of assets unrelated to QE polices is assumed to be constant relative to nominal GDP at recent levels. The country-specific assumptions are as follows::

1. The first 3-year LTRO of €489.2 billion was introduced on 21 December 2011 and the second of $€ 529.5$ billion on 29 February 2012. In the second programme, net new borrowing was actually around $€ 313$ billion as $€ 215$ billion of existing lending was rolled into it. 
- In the euro area, the size of 3-year LTRO assets decreases linearly until February 2015, reflecting earlier repayments observed so far. In the absence of detailed data, the outstanding amount of assets purchased through covered bond purchasing programmes and the Securities Markets Programme decreases linearly from recent levels over 10 years after the start of the respective programmes.

- In Japan, the composition of planned future asset purchases is kept constant until early 2015. These assets purchases cease in April 2015. The outstanding amount of other purchased assets, such as ETFs and REITs, is wound down linearly over 10 years from April 2015.

- In the United States, the Fed continues to buy assets until October 2014 with the same maturity structure, but the monthly amount of mortgage-backed securities and of Treasury securities is lowered on average by around 10 billion dollars starting in January 2014. Principal payments from maturing assets are reinvested in assets with the same maturities. Between November 2014 and December 2015, these assets are kept constant nominally thanks to reinvestments.

- In the United Kingdom, the BoE keeps the size of Asset Purchase Facility unchanged until end2015, reinvesting principal payments evenly across several maturity tranches. From January 2016, assets are let to mature.

The projections based on those assumptions imply that in the euro area, assets would decline by almost $10 \%$ of GDP within one and half years; in Japan, they would drop by more than $40 \%$ of GDP in 10 years, while in the United States and the United Kingdom they would fall by around $10 \%$ of GDP within the same period, which still involves a considerable adjustment with the potential to affect market conditions (Figure A1.1). 
Figure A1.1. Projections of central banks total assets

In per cent of GDP

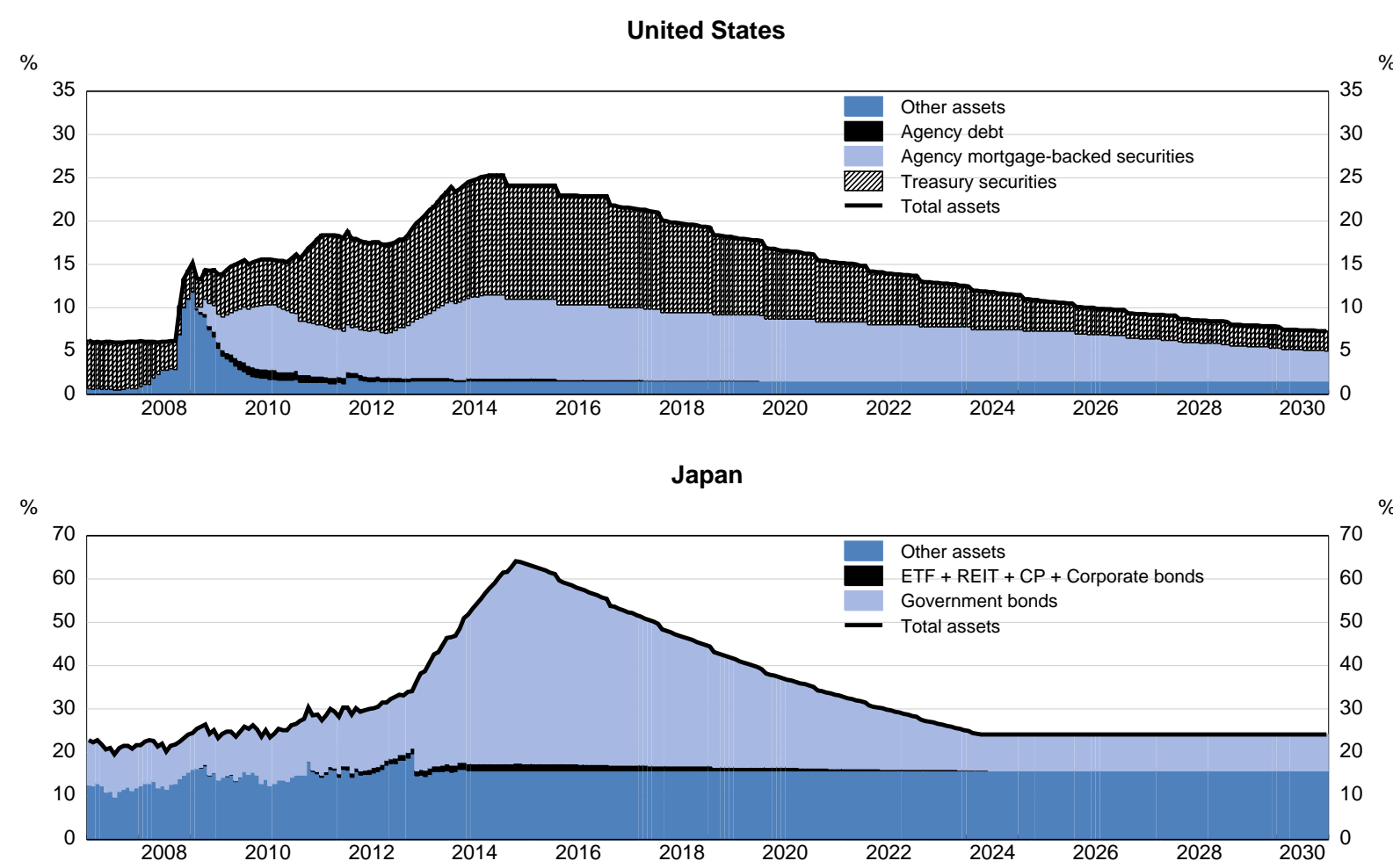

Euro area

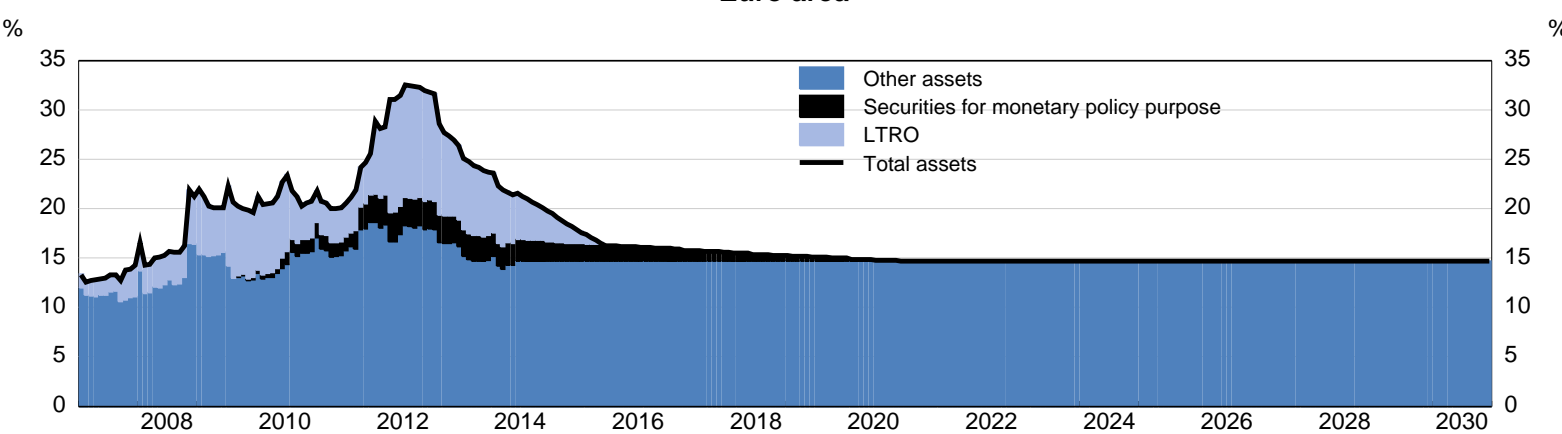

United Kingdom

$\%$

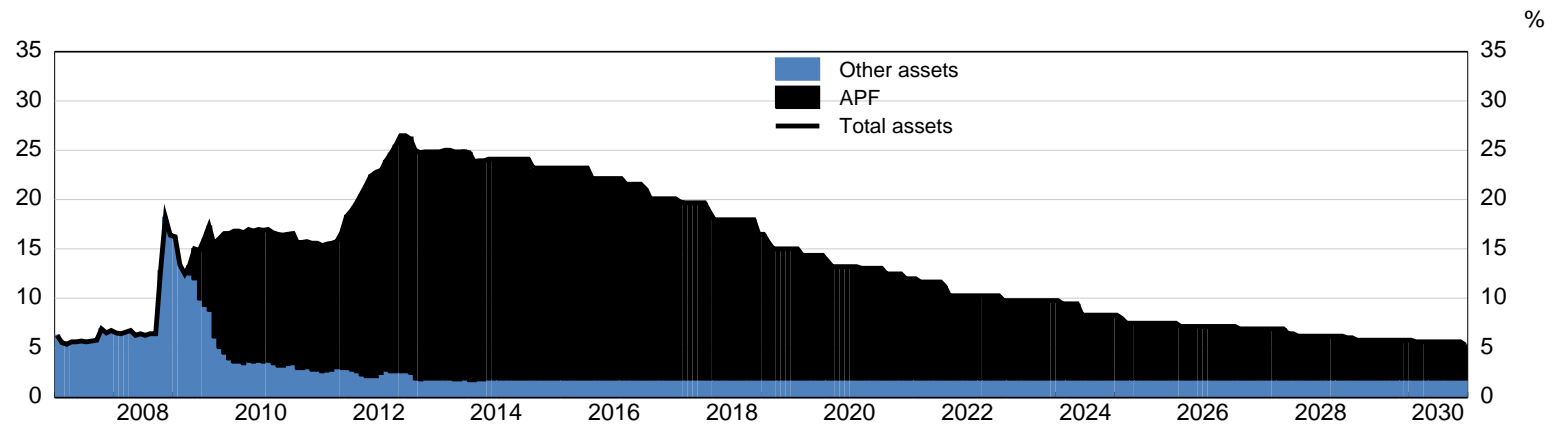

Source: Bank of England; Bank of Japan; European Central Bank; Federal Reserve; OECD Economic Outlook 94 database; and OECD calculations. 


\section{APPENDIX 2. CO-MOVEMENTS IN FINANCIAL MARKETS}

This appendix briefly summarises selected findings from the literature about co-movements in financial markets and discusses the evolution of correlations between changes in equity prices and long-term government bond yields in the United States and selected OECD and BRIICS economies.

In highly integrated global financial markets, asset prices tend to co-move across countries, though the intensity and sign of this co-movement vary across economies, asset classes and over time. ${ }^{1}$ There is some evidence that cross-country co-movements have increased over the past decades. Bekaert et al. (2009) show that the response of stock market returns to global factors increased between 1980 and 2005 only in Europe but not in other developed countries that were analysed. Blackburn and Chidambaran (2011), employing an alternative method of identifying global factors for the same group of countries which results in a larger estimate of common factors, find a more widespread increase in the responsiveness after mid-1990s. Arguments for higher positive cross-country correlation refer to increasing global integration and stock market bubbles in the 2000s, with some empirical evidence favouring the latter hypothesis (Brooks and Del Negro, 2004). Regarding emerging markets economies (EMEs), Ammer et. al. (2010) show increasing co-variation between stock prices in EMEs and advanced economies over the 1993-2009 period, and argue that it was driven by global market integration and declining country-specific volatility in EMEs' equity prices.

Analysis of correlations between changes in equity prices in the United States and in selected OECD countries and BRIICS show that positive correlation increased in the 1990s and then remained broadly stable and high for most of the analysed advanced OECD countries, with Japan being somewhat an exception where the correlation is clearly lower (Table A2.1). A similar increase was observed for the BRIICS, but in recent years the correlation has been generally lower than for the advanced OECD countries, especially in China and Indonesia. A comparable picture emerges from the analysis of correlations between changes in 10-year government bond yields in the United States and other countries (Table A2.2). However, idiosyncratic movements in the euro area in 2011-12, relating to the escalation of sovereign crisis in some euro area countries, lowered the correlation with the United States. Bond yield correlations for the BRIICS tend to be noticeably lower than for equity prices, in some cases being even negative. Since correlations in equity prices and government bond yields say nothing about the underlying causes, it is difficult to draw conclusions for future developments. Nevertheless, some persistence of the recent high correlations can be expected. Thus, policymakers should be prepared for dealing with consequences of international spillovers.

1. Cross-country financial market co-movements are often measured by correlation coefficients for asset prices, like equities, government and corporate bonds, or for risk indicators, like spreads in credit default swaps and sovereign bonds, or for the volatility of asset prices. Another approach utilises a multi-factor model of asset returns based on the finance theory, in which asset returns are determined by common factors, which represent non-diversifiable risks, as well as idiosyncratic factors, which represent diversifiable risks, where a higher coefficient on common factors implies tighter international comovement. 
ECO/WKP(2014)12

Table A2.1. Correlation of changes in equity prices

\begin{tabular}{|c|c|c|c|c|c|c|c|c|c|c|c|c|c|c|c|c|c|}
\hline & BEL & CAN & DEU & FRA & ITA & JPN & NLD & SWE & CHE & GBR & EA & BRA & CHN & IDN & IND & RUS & ZAF \\
\hline 1993 & 0.22 & 0.36 & 0.20 & 0.34 & & 0.15 & & 0.41 & 0.26 & 0.32 & & & & -0.15 & -0.09 & & \\
\hline 1994 & 0.35 & 0.60 & 0.16 & 0.42 & & 0.31 & & 0.47 & 0.43 & 0.54 & & 0.22 & & 0.49 & 0.29 & & \\
\hline 1995 & 0.28 & 0.57 & 0.28 & 0.20 & & 0.12 & 0.35 & 0.36 & 0.31 & 0.58 & & 0.13 & & 0.46 & 0.10 & & -0.12 \\
\hline 1996 & 0.27 & 0.53 & 0.28 & 0.10 & & 0.11 & 0.32 & 0.50 & 0.01 & 0.29 & & 0.28 & & 0.14 & 0.12 & & -0.13 \\
\hline 1997 & 0.67 & 0.83 & 0.63 & 0.67 & & 0.41 & 0.70 & 0.69 & 0.50 & 0.56 & 0.31 & 0.39 & & 0.56 & 0.07 & 0.09 & 0.27 \\
\hline 1998 & 0.76 & 0.81 & 0.73 & 0.76 & 0.43 & 0.57 & 0.80 & 0.82 & 0.76 & 0.78 & 0.84 & 0.65 & & 0.52 & 0.33 & 0.33 & 0.59 \\
\hline 1999 & 0.63 & 0.87 & 0.78 & 0.76 & 0.74 & 0.52 & 0.76 & 0.74 & 0.78 & 0.83 & 0.83 & 0.47 & & 0.50 & 0.18 & 0.50 & 0.56 \\
\hline 2000 & 0.59 & 0.54 & 0.44 & 0.51 & 0.17 & 0.47 & 0.55 & 0.28 & 0.65 & 0.73 & 0.66 & 0.55 & & 0.33 & -0.02 & 0.44 & 0.39 \\
\hline 2001 & 0.50 & 0.74 & 0.76 & 0.78 & 0.62 & 0.52 & 0.77 & 0.72 & 0.70 & 0.82 & 0.81 & 0.62 & & 0.27 & 0.47 & 0.47 & 0.72 \\
\hline 2002 & 0.63 & 0.91 & 0.88 & 0.90 & 0.85 & 0.63 & 0.88 & 0.88 & 0.87 & 0.87 & 0.90 & 0.71 & .. & 0.09 & 0.55 & 0.45 & 0.68 \\
\hline 2003 & 0.77 & 0.84 & 0.84 & 0.89 & 0.84 & 0.32 & 0.85 & 0.80 & 0.85 & 0.84 & 0.88 & 0.59 & & 0.24 & 0.20 & 0.31 & 0.49 \\
\hline 2004 & 0.64 & 0.76 & 0.73 & 0.77 & 0.62 & 0.41 & 0.70 & 0.68 & 0.68 & 0.62 & 0.77 & 0.53 & & 0.58 & 0.41 & 0.35 & 0.57 \\
\hline 2005 & 0.51 & 0.66 & 0.79 & 0.68 & 0.66 & 0.38 & 0.67 & 0.64 & 0.63 & 0.64 & 0.73 & 0.45 & -0 & 0.39 & 0.49 & 0.09 & 0.56 \\
\hline 2006 & 0.55 & 0.68 & 0.71 & 0.70 & 0.72 & 0.49 & 0.70 & 0.65 & 0.72 & 0.73 & 0.76 & 0.50 & & 0.38 & 0.57 & 40 & 0.57 \\
\hline 2007 & 0.82 & 0.69 & 0.85 & 0.86 & 0.84 & 0.60 & 0.78 & 0.75 & 0.79 & 0.78 & 0.84 & 0.70 & & 0.64 & 0.69 & 0.45 & 0.68 \\
\hline 2008 & 0.87 & 0.82 & 0.86 & 0.89 & 0.85 & 0.82 & 0.90 & 0.89 & 0.89 & 0.90 & 0.90 & 0.71 & ) & 0.52 & 0.62 & 59 & 0.70 \\
\hline 2009 & 0.86 & 0.88 & 0.94 & 0.92 & 0.88 & 0.83 & 0.89 & 0.83 & 0.89 & 0.89 & 0.92 & 0.79 & 0.19 & 0.75 & 0.82 & 0.67 & 0.82 \\
\hline 2010 & 0.82 & 0.88 & 0.88 & 0.90 & 0.85 & 0.67 & 0.88 & 0.79 & 0.82 & 0.91 & 0.89 & 0.82 & 0.2 & 0.69 & 0.70 & 0.70 & 0.86 \\
\hline 2011 & 0.80 & 0.79 & 0.80 & 0.87 & 0.75 & 0.68 & 0.91 & 0.79 & 0.76 & 0.90 & 0.85 & 0.61 & 0.45 & 0.39 & 0.44 & 0.66 & 0.84 \\
\hline 2012 & 0.80 & 0.84 & 0.85 & 0.84 & 0.74 & 0.69 & 0.86 & 0.89 & 0.76 & 0.91 & 0.87 & 0.80 & & 0.59 & 0.67 & 0.74 & 0.76 \\
\hline 2013 & 0.77 & 0.75 & 0.76 & 0.68 & 0.61 & 0.58 & 0.69 & 0.77 & 0.74 & 0.81 & 0.76 & 0.66 & 0.27 & 0.49 & 0.55 & 0.70 & 0.45 \\
\hline
\end{tabular}

Note: The table shows annual averages of the correlation of 20-day changes in equity prices between the United States and the countries analysed, calculated over the 260-day rolling window.

Source: OECD calculations based on Datastream data.

Table A2.2. Correlation of changes in 10-year government bond yields

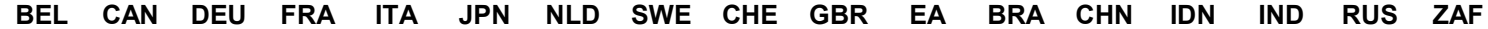

\begin{tabular}{|c|c|c|c|c|c|c|c|c|c|c|c|c|c|c|c|c|c|}
\hline 1993 & -0.18 & 0.50 & 0.35 & 0.04 & -0.14 & 0.42 & 0.24 & -0.07 & 0.25 & -0.07 & 0.16 & & & & & & \\
\hline 1994 & 0.15 & 0.70 & 0.43 & 0.55 & 0.33 & 0.19 & 0.52 & 0.33 & 0.33 & 0.50 & 0.49 & .. & .. & .. & .. & 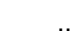 & \\
\hline 1995 & 0.32 & 0.68 & 0.40 & 0.35 & -0.03 & 0.39 & 0.41 & 0.18 & 0.10 & 0.35 & 0.24 & .. & .. & .. & .. & .. & .. \\
\hline 1996 & 0.53 & 0.85 & 0.64 & 0.35 & 0.17 & 0.36 & 0.56 & 0.33 & 0.11 & 0.53 & 0.40 & $\cdot$. & .. & .. & H & 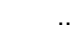 & - \\
\hline 1997 & 0.64 & 0.88 & 0.72 & 0.61 & 0.60 & 0.09 & 0.66 & 0.36 & 0.37 & 0.60 & 0.67 & .. & .. & .. & .. & .. & .. \\
\hline 1998 & 0.62 & 0.79 & 0.61 & 0.57 & 0.58 & 0.15 & 0.63 & 0.48 & 0.30 & 0.55 & 0.62 & .. & .. & .. & .. & .. & .. \\
\hline 1999 & 0.69 & 0.84 & 0.69 & 0.68 & 0.63 & 0.16 & 0.72 & 0.44 & 0.25 & 0.68 & 0.69 & .. & .. & .. & .. &.. & .. \\
\hline 2000 & 0.69 & 0.88 & 0.68 & 0.70 & 0.71 & -0.13 & 0.69 & 0.57 & 0.39 & 0.60 & 0.71 & $\cdot \cdot$ & .. & .. & .. & .. & -0.10 \\
\hline 2001 & 0.79 & 0.90 & 0.81 & 0.77 & 0.76 & 0.21 & 0.80 & 0.67 & 0.63 & 0.62 & 0.78 & $\cdot$. & .. & .. & $\cdot$. & .. & 0.26 \\
\hline 2002 & 0.82 & 0.89 & 0.83 & 0.82 & 0.78 & -0.02 & 0.82 & 0.70 & 0.75 & 0.79 & 0.80 & .. & .. & .. & .. & .. & 0.43 \\
\hline 2003 & 0.82 & 0.84 & 0.84 & 0.82 & 0.82 & 0.04 & 0.82 & 0.78 & 0.67 & 0.83 & 0.83 & $\cdot \cdot$ & .. & .. & .. & 0.31 & 0.13 \\
\hline 2004 & 0.87 & 0.89 & 0.85 & 0.86 & 0.87 & 0.36 & 0.86 & 0.81 & 0.70 & 0.74 & 0.86 & ". & 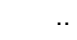 & 0.14 & & 0.30 & 0.38 \\
\hline 2005 & 0.74 & 0.85 & 0.77 & 0.78 & 0.74 & 0.44 & 0.76 & 0.72 & 0.65 & 0.71 & 0.77 & .. & .. & 0.08 & .. & 0.22 & 0.40 \\
\hline 2006 & 0.86 & 0.90 & 0.86 & 0.86 & 0.85 & 0.73 & 0.86 & 0.81 & 0.72 & 0.84 & 0.86 & -0.12 & .. & -0.13 & 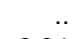 & 0.43 & 0.20 \\
\hline 2007 & 0.92 & 0.94 & 0.92 & 0.92 & 0.90 & 0.78 & 0.91 & 0.91 & 0.83 & 0.89 & 0.92 & -0.21 & 0.00 & -0.24 & -0.04 & -0.01 & 0.22 \\
\hline 2008 & 0.79 & 0.87 & 0.85 & 0.84 & 0.82 & 0.80 & 0.84 & 0.81 & 0.77 & 0.82 & 0.85 & -0.26 & -0.07 & -0.13 & 0.31 & -0.12 & 0.19 \\
\hline 2009 & 0.72 & 0.89 & 0.78 & 0.74 & 0.57 & 0.61 & 0.66 & 0.76 & 0.60 & 0.77 & 0.74 & 0.39 & 0.18 & 0.49 & 0.50 & -0.52 & 0.59 \\
\hline 2010 & 0.60 & 0.89 & 0.81 & 0.71 & 0.30 & 0.59 & 0.71 & 0.64 & 0.54 & 0.74 & 0.72 & -0.26 & 0.07 & -0.15 & 0.29 & -0.14 & 0.04 \\
\hline 2011 & 0.62 & 0.87 & 0.84 & 0.83 & 0.45 & 0.71 & 0.85 & 0.85 & 0.75 & 0.85 & 0.83 & 0.33 & 0.28 & 0.30 & -0.03 & -0.22 & 0.24 \\
\hline 2012 & 0.08 & 0.91 & 0.73 & 0.39 & -0.17 & 0.67 & 0.67 & 0.84 & 0.80 & 0.81 & 0.29 & 0.35 & 0.07 & -0.02 & 0.26 & -0.24 & 0.29 \\
\hline 2013 & 0.51 & 0.92 & 0.77 & 0.56 & -0.12 & 0.59 & 0.67 & 0.82 & 0.81 & 0.87 & 0.39 & 0.42 & 0.45 & 0.24 & 0.05 & 0.01 & 0.45 \\
\hline
\end{tabular}

Note: The table shows annual averages of the correlation of 20-day changes in 10-year government bond yields between the United States and the countries analysed, calculated over the 260-day rolling window.

Source: OECD calculations based on Datastream data. 
There are also controversies whether co-movement increases during turbulent times - a phenomenon often referred to as contagion. They relate to challenges in obtaining robust evidence of contagion due to econometric problems associated with the statistical tests applied, including endogeneity, omitted common factors and rising volatility (Dungey et. al., 2005; and Forbes, 2012). ${ }^{2}$ Developments during the recent financial crisis seem to tentatively suggest that the intensity of shock transmission did not increase. For instance, Caporin et al. (2013) find no evidence for contagion when analysing CDS spreads and bond premia for major euro area countries during 2008 to $2011 .^{3}$ There are, however, several mechanisms that can explain strong spillovers of negative shocks, including liquidity considerations and information asymmetries (Claessens et al., 2001).

Regarding liquidity considerations, losses on investment in one country may induce investors to liquidate their investment positions in other countries or in other asset classes in anticipation of higher redemptions or due to internal rules or regulatory limits, especially when investors are leveraged. In particular, when the negative shock occurs, value-at-risk models could trigger selling of higher risk assets (Schinasi and Smith, 2000). The diversification of risks may also imply that a negative shock in one country may spill over to countries with similar risk characteristics and close correlations during normal times (Kaminsky and Reinhart, 1998). The liquidity mechanisms may paradoxically lead to shock spillovers to countries with more liquid markets, as leveraged investors could keep their assets whose prices already declined and where secondary markets have become less liquid and sell assets in still not distressed markets (Claessens et al., 2001).

Negative spillovers could also be strengthened by asymmetric information leading to herd behaviour. Acute financial problems in one country may make investors expect similar problems in another country unless extensive information on its economic conditions is available. More generally, costly collection and processing of information, especially in foreign countries, and other kinds of transaction costs (such as costs of short-selling) encourage investors to imitate the same global market portfolio, making them react in the same fashion to shocks (Calvo and Mendoza, 2000). Although active funds are essential for efficient financial markets, informational opaqueness about such funds may discourage final investors to invest in them and together with other transaction costs could prevent a full arbitrage (Gromb and Valanos, 2010). Financial asset price co-movements may also increase with the prevalence of index funds (Vayanos and Wooley, 2010). The heterogeneity of investors, however, may not always be beneficial for efficient financial markets. When some investors have private information, other investors may find it beneficial to follow well-informed investors (Allen et. al., 2006; and Bacchetta et. al, 2008).

Contagion is more likely with higher real and financial integration into the global economy and weaker fundamentals. Forbes (2012) finds in particular that a country is more likely to experience extreme negative equity returns if it has more leveraged banks, greater trade exposure, weaker macro-fundamentals and larger international portfolio liabilities, while larger international portfolio investment assets and less reliance on debt (versus equity) for international financing reduces such a possibility. ${ }^{4}$

2. For instance, the upward bias in correlation resulting from rising heteroskedasticity during financial turmoil can be modified by statistical techniques as suggested, for instance, by Karolyi and Stulz (1996) and Corsetti et al. (2011), although such solutions can be problematic as they depend on assumptions which are often not met in practice (Forbes, 2012).

3. Increased co-movements were driven by stronger common shocks and higher hetroskedasticity and not by the change in the transmission of shocks among the countries analysed.

4. Forbes (2012) applies the extreme value method, which estimates the probability of an extreme event - in her case extreme negative equity return - in a given country conditional on the occurrence of such events in other countries. 


\section{BIBLIOGRAPHY}

Allen, F., S. Morris, and H.S. Shin (2006), "Beauty Contests and Iterated Expectations in Asset Markets", The Review of Financial Studies, Vol. 19, pp. 719-752.

Ammer, J., F. Cai, and C. Scotti (2010), "Has International Financial Co-Movement Changed? Emerging Markets in the 2007-2009 Financial Crisis", Board of Governors of the Federal Reserve System International Finance Discussion Papers, No. 1006, September.

Bacchetta, P. and E.V. Wincoop (2008), "Higher Order Expectations in Asset Pricing", Journal of Money, Credit, and Banking, Vol. 40, pp. 837-866.

Bekaert, G., R.J. Hodrick, and X. Zhang (2009), "International Stock Return Comovements”, Journal of Finance, Vol. 64, pp. 2591-2626.

Blackburn, D.W. and N.K. Chidambaran (2013), "Is World Stock Market Comovement Changing?", mimeo.

Brooks, R. and M. Del Negro (2004), "The Rise in Comovement across National Stock Markets: Market Integration or IT Bubble?”, Journal of Empirical Finance, Vol. 11(5), pp. 659-680, December.

Calvo, G. and E. Mendoza (2000), "Rational Contagion and the Globalization of Securities Markets", Journal of International Economics, Vol. 51, pp. 79-113.

Caporin, M., L. Pelizzon, F. Ravazzolo, and R. Rigobon (2013), "Measuring Sovereign Contagion in Europe", NBER Working Paper Series, No. 18741.

Claessens, S., Dornbusch, R., and Y.C. Park (2001), "Contagion: Why Crises Spread and How This Can Be Stopped?", in Claessens, S. and K. Forbes (eds), International Financial Contagion, Springer US, pp. 19-41.

Corsetti, G., M. Pericoli, and M. Sbracia (2011), "Correlation Analysis of Financial Contagion”, in R.W. Kolb (ed.), Financial Contagion: The Viral Threat to the Wealth of Nations.

Dungey, M., R. Fry, B. Gonzalez-Hermosillo, and V.L. Martin (2005), "Empirical Modelling of Contagion: a Review of Methodologies", Quantitative Finance, Vol. 5, pp. 9-24.

Forbes, C. (2012), “The “BIG C”: Identifying Contagion”, NBER Working Paper Series, No. 18465.

Gromb, D. and D. Vayanos (2010), "Limits of Arbitrage”, Annual Review of Financial Economics, Vol. 2, pp. 251-275.

Karolyi, A. and R. Stulz (1996), "Why Do Markets Move Together? An Investigation of US-Japan Stock Return Comovements", Journal of Finance, Vol. 51, pp. 951-986.

Schinasi, G.J. and R.T. Smith (2000), "Portfolio Diversification, Leverage, and Financial Contagion", IMF Staff Papers, Vol. 47, No. 2, pp. 159-176.

Vayanos, D. and P. Woolley (2011), "Fund Flows and Asset Prices: A Baseline Model”, The Paul Woolley Centre Working Paper Series, No. 18, London School of Economics. 


\section{APPENDIX 3. RISKS IN CHINA'S FINANCIAL SYSTEM AND POTENTIAL INTERNATIONAL SPILLOVERS}

This appendix discusses potential systemic risks in the Chinese financial system and the likelihood of international spillovers.

The regular commercial banking sector has become large, with total assets exceeding $200 \%$ of GDP by end-2012 (Table A3.1), i.e. below the average for the OECD countries but significantly above other BRIICS. This was associated with a rapid expansion of domestic claims of depositary institutions (comprising commercial banks, the central bank, and other banking institutions), increasing by $30 \%$ of GDP between 2008 and 2012, when they reached 155\% of GDP. Such a fast pace, which often has presaged financial crises for advanced countries in the past (Zhang and Chen, 2013), raises credit quality and financial stability concerns, especially as economic growth looks set to be weaker in the coming years than in the past five years. The formal commercial banking sector seems, however, well capitalised (Table A3.1) and is in a transition to more stringent regulation than envisaged in Basel III. Non-performing loans are small and banks have made sizeable loss provisions. This suggests that banks have large buffers to absorb losses in case of a negative shock. Nevertheless, some of the banking indicators may not adequately account for off-balance sheet exposures and several risks are present.

Table A3.1. Selected indicators of the banking sector ${ }^{1}$

\begin{tabular}{|c|c|c|c|c|c|c|c|c|}
\hline & & 2007 & 2008 & 2009 & 2010 & 2011 & 2012 & 2013 \\
\hline \multirow{2}{*}{$\begin{array}{c}\text { Banking } \\
\text { institutions }\end{array}$} & Total assets (CNY tr) & 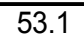 & 63.2 & 79.5 & 95.3 & 113.3 & $\overline{133.6}$ & $\overline{151.4}$ \\
\hline & Total assets ( $\%$ of GDP) & 199.8 & 201.1 & 233.2 & 237.4 & 239.5 & 257.5 & 266.2 \\
\hline \multirow{8}{*}{$\begin{array}{c}\text { Commercial } \\
\text { banks }\end{array}$} & 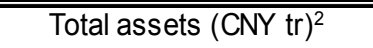 & 41.0 & (47.8 & 61.5 & 74.2 & 88.4 & 104.6 & 1117.4 \\
\hline & Total assets ( $\%$ of GDP) & 154.2 & 152.3 & 180.4 & 184.7 & 186.9 & 201.5 & 206.4 \\
\hline & Liquidity ratio & 37.7 & 46.1 & 42.4 & 42.2 & 43.2 & 45.8 & 44.0 \\
\hline & NPL ratio & 6.1 & 2.4 & 1.6 & 1.1 & 1.0 & 1.0 & 1.0 \\
\hline & Provisioning coverage ratio & 41.4 & 116.6 & 153.2 & 217.7 & 278.1 & 295.5 & 282.7 \\
\hline & Leverage ratio 2,3 & 5.5 & 6.0 & 5.5 & 6.1 & 6.4 & 6.5 & 7.1 \\
\hline & Capital adequacy ratio 4 & n.a. & n.a. & 11.4 & 12.2 & 12.7 & 13.3 & 12.2 \\
\hline & Core capital adequacy ratio ${ }^{5}$ & n.a. & n.a. & 9.2 & 10.1 & 10.2 & 10.6 & 10.0 \\
\hline
\end{tabular}

1. In per cent unless indicated otherwise.

2. The 2013 figure is based on OECD's estimations of rural commercial and foreign banks' total assets and liabilities.

3. Total owner's equity over total assets.

4. Net tier 1 capital over risk-weighted assets.

5. The data for 2013 is not fully comparable with previous years due to a change of methodology for calculation.

Source: China Banking Regulatory Commission (CBRC).

Credit expansion has been increasingly taking place outside the regular banking sector, leading to a rapid expansion of the so-called shadow banking sector (Figure A3.1), even if it is still relatively small compared with many advanced OECD countries (FSB, 2013). Estimates of the size of the shadow banking sector range widely, between $44 \%$ and $69 \%$ of GDP as of end-2012. ${ }^{1}$ Shadow banking has boomed in

1. In line with the PBOC (2013) definition, the shadow banking sector refers here to credit intermediation, involving entities and activities outside the regular banking system, with the functions of liquidity and credit transformation. Depending on which financial facilities are covered, there are several estimates of the size of shadow banking, such as Tao and Deng (2013) (43.9\% of GDP), Standard \&Poor's (2013) (44.1\% of GDP), Ueda and Gomi (2013) (64.4\% of GDP), and Zhu et al. (2013) (69.4\% of GDP). 
response to tighter regulation of regular banking activity to damp credit growth since 2010 and to caps on deposit interest rates, in an environment of unmet demand for credit and search for higher yield by wealthy individuals and cash-rich enterprises. The most popular shadow banking products include wealth management products (WMPs) and trust products (TPs), which together are estimated to account for over $30 \%$ of GDP at end-2013 (Box Figure below). The former are short-term (up to one-year) investment products. Regulated banks sell WMPs and manage pooled money off-balance sheet by investing mainly in longer-term fixed-income bonds. The WMPs allow selling banks to shift some of the assets off balance sheet to reduce obligatory deposit reserves and to report a good deposit base by setting the expiration date of WMPs for the end of reference period (IMF, 2012b), which is longer than the maintenance period of reserve requirements. The TPs are longer-term investment products, and trust companies lend funds entrusted by their clients to real-estate and industrial projects as well as investing them in financial products.

Shadow and regular banks are exposed to Local Government Financing Vehicles (LGFVs), by making loans to them and investing in their bonds, which risks undermining the asset quality of the banks. The LGFVs were established by local governments to finance infrastructure and public real estate projects. Their debt increased rapidly over recent years to an estimated CNY 19 trillion, or 37\% of GDP, at end2012, with some analysis suggesting that nearly half of this debt would be non-performing without fiscal subsidies and special accounting practices enabling LGFVs to understate financial costs by capitalising interest expenses (Zhang et al., 2013).

\section{Figure A3.1. Credit has increased rapidly}
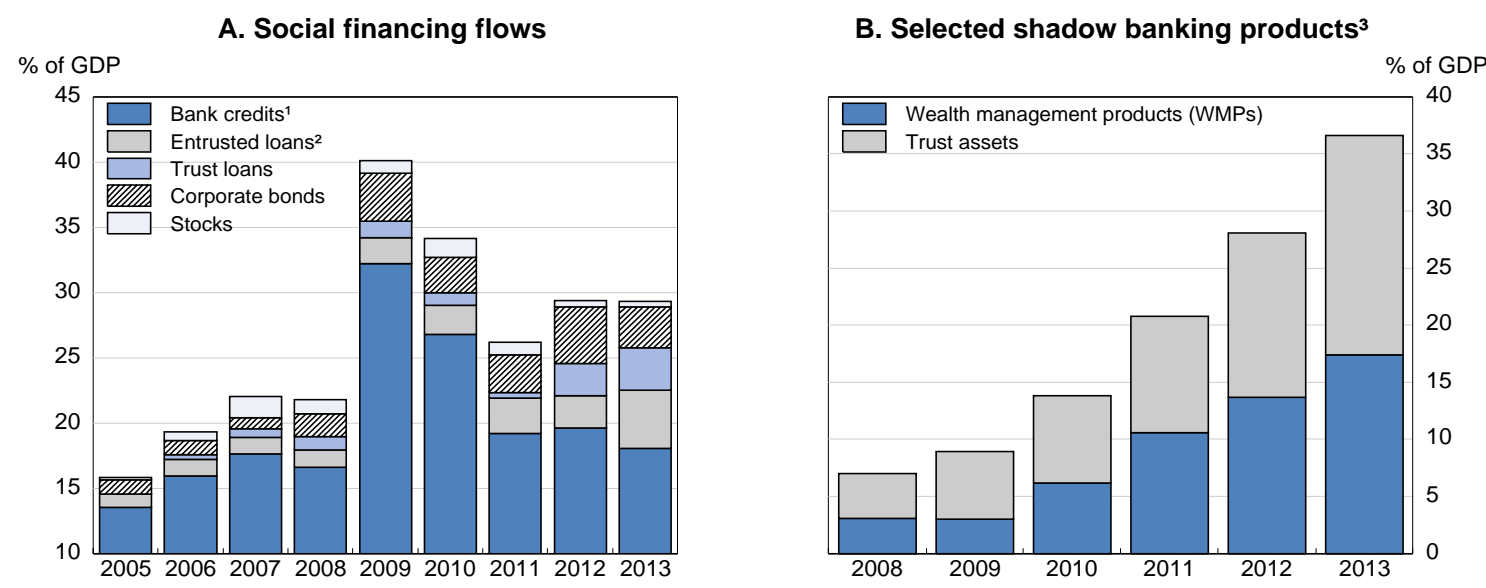

1. Including bank loans denominated in local and foreign currencies as well as bank's acceptance bills.

2. Business-to-business loans by bank intermediation.

3. The year-end outstanding balances are referred to, although the value of WMPs for 2013 is as of end-September. Possible overlaps between the WMPs and trust assets, or the WMPs sold by trust companies, are not adjusted.

Source: People's Bank of China, CBRC, Kwan (2014), National Bureau of Statistics of China, and China Trustee Association.

The banking sector is sensitive to declines in real estate prices given that nearly $30 \%$ of total bank loans, including loans to LGFVs, are allocated to the real estate sector. ${ }^{2}$ Falling prices will reduce the actual and expected profitability of real-estate projects, on which their repayment capacity depends, thereby jeopardising creditors. The negative consequences of this could be amplified by negative feedback effects between the real economy, real estate prices and the financial sector. Such feedbacks would largely 
depend on the feasibility for, and the willingness of, local governments to give fiscal supports to failing LGFVs, with implications for their creditors. Local governments, however, have almost no freedom to change the tax rate and base (OECD, 2013a) and their revenues largely depend on land sales (IMF, 2013). Thus, lower revenues could entail reduced financial support to LGFVs and in turn curtail public investment and weaken bank balance sheets. If so, local governments might be encouraged to accelerate the sale of land, amplifying the initial price declines (OECD, 2013b).

There is also the risk of a run on shadow banking products, as most of them do not come with an explicit guarantee of the principal. If individual shadow banking products were to default, leading to losses of principal, a general run on shadow banking products could not be excluded. This risk, however, will be mitigated if selling banks and trust companies bail out failed shadow banking products for fear of reputational damage, although such bailouts would be associated with higher demand by rescuing financial institutions for liquidity. Such a risk could materialise this year as a large part of TPs is set to mature in 2014. This illustrates the strong interconnectedness between regular banks and shadow banking products, highlighting the systemic importance of these products.

The risk of a systemic crisis in China's financial system will depend on the authorities' response. They have already implemented some micro-prudential regulations to limit LGFVs financing and increase the level of oversight of the WMPs, but it remains to be seen if they will be effective. ${ }^{3}$ The government seems to have enough fiscal space to bail out failed LGFVs and financial institutions to minimise the risk of contagion. The central government is a major landowner and shareholder (Ueda and Gomi, 2013) and its official debt was CNY 9.4 trillion (18\% of GDP) at end-2012 (National Audit Office, 2013). However, the fiscal cost could be very high, reflecting sizeable governmental contingent liabilities and the underestimation of the size of LGFVs' liabilities. ${ }^{4}$ Such intervention could also aggravate moral hazard problems. The recent rescue of a TP institution (Credit Equals Gold No.1) may underpin individual investors' opportunistic beliefs in future bailouts by related financial institutions and governments.

The risk of international financial and trade spillovers could be larger than expected from direct linkages alone. The Chinese banking sector is not deeply integrated with global financial markets, implying limited financial spillovers. Foreign banks accounted for less than $2 \%$ of total banking sector assets as of end-2012, and financial claims on Chinese banks of the OECD countries are very small (below $1 \%$ of GDP, with the exception of the United Kingdom). Financial turbulence in China could, however, weaken further international investors' asset values and sentiment, with negative implications for financial stability in other EMEs. This spillover could in particular go through Hong Kong where large Chinese

3. The National Development and Reform Commission tightened the eligibility criteria of corporate bond issuance in December 2012 and reformed its investigation and approval process in April 2013. The China Banking Regulatory Commission strengthened supervision of WMPs in March 2013 and capped total bank loans to the LGFVs in May 2013. In February 2014, the PBOC introduced regulation to shorten the maturity of financial assets of WMPs.

4. The debt-to-GDP ratio covers explicit government debt only. If contingent liabilities for which the government co-signs, as well as those for which the government does not assume the juridical responsibility of repayment but commits to supporting failed debtors, are taken into account, the central government's debt-to-GDP ratio would have been 23\% at end-2012. Likewise, general government's debtto-GDP ratio would have been $54 \%$ at that time. Debt would be even larger if LGFVs' debt is fully accounted for. Zhang et al. (2013) suggest that the recent survey by the National Audit Office (2013) on local government and LGFVs debt could involve an underestimation of local government debt in 2012 by around 12.8 trillion due to underreporting of LGFVs liabilities. Adjusting for this, local and general government debts as of end-2012 would be CNY 28.7 trillion and CNY 40.6 trillion (78\% of GDP), respectively. 
companies and banks have a significant presence in equity markets. ${ }^{5}$ With credit-dependent economic growth, the policy-induced slowdown in credit or financial turmoil in the banking sector could damp domestic growth and spill over to other countries via trade. Simulations of the NiGEM model suggest that a 2-percentage point decline in domestic demand growth during one year could reduce OECD growth by $0.1 \%$, with a somewhat stronger impact in Japan and some other BRIICS. This relatively small impact is found in other studies (e.g. by IMF, 2012a) and seems to reflect the fact that China is not yet a dominant export destination for OECD countries and a part of its imports is re-exported and thus dependent on demand outside China (Ollivaud et al., 2014). However, such simulations fail to account for confidence effects and disruptions of global value chains with knock-on effects on production and profits in other countries. Slower Chinese growth could also lower commodity prices as China is the largest consumer of many commodities. ${ }^{6}$

5. For example, the market capitalisation of an index of representative 40 Chinese companies (so-called HShares) amounted to USD 317 billion, accounting for 10\% of the overall Hong Kong stock market at end2013. This was equivalent to $2 \%$ and $7 \%$ of the market capitalisation of New York Stock Exchange and Tokyo Stock Exchange, respectively, at end-2013. Meanwhile, the market capitalisation of all internationally-tradable shares (B-Shares) in Shanghai and Shenzhen was USD 30 billion at end-2013.

6. According to IMF (2012a), a temporary 1\% decline of China's real fixed-asset investment would reduce commodity prices (for example, by $1.3 \%$ for metals) and the growth rate of PPP-weighted G20 GDP by 0.06 percentage point after 4 quarters, with the effects persisting up to 8 quarters. 


\section{BIBLIOGRAPHY}

CBRC (2013), CBRC 2012 Annual Report, China Banking Regulatory Commission, May.

FSB (2013), Global Shadow Banking Monitoring Report 2013, Financial Stability Board, 14 November.

IMF (2012a), 2012 Spillover Report - Background Papers, July.

IMF (2012b), Global Financial Stability Report, October.

IMF (2013), Fiscal Monitor: Fiscal Adjustment in an Uncertain World, April.

Kwan, C.H. (2014), "Shadow Banking in China: Current Situation and Challenges", China in Transition, Research Institute of Economy, Trade \& Industry.

National Audit Office (2013), Report of Auditing Results of Nationwide Government Debt, No. 32, 30 December.

OECD (2013a), OECD Economic Surveys: China 2013, OECD Publishing.

OECD (2013b), OECD Economic Outlook, Vol. 2013/2, OECD Publishing.

POBC (2013), China Financial Stability Report 2013, People’s Bank of China.

POBC (2014a), Financial Statistics, 2013, People's Bank of China, 16 January.

POBC (2014b), Statistical Report on Uses of Loans by Financial Institutions, 2013, People's Bank of China, 8 February.

Standard \& Poor's (2013), "Why Shadow Banking is yet to Destabilize China's Financial System", Credit FAQ, 27 March.

Tao, D. and W. Deng (2013), "China: Shadow Banking - Road to Heightened Risks", Economics Research, Credit Suisse, 22 February.

Ueda, K. and Y. Gomi (2013), "Shadow Banking in China and Expanding Debts of Local Governments", Newsletter, No. 23, Institute for International Monetary Affairs.

Zhang, Z., H. Changchun, and W. Chen (2013), “China's Heavy LGFV Debt Burden”, Asia Special Report, Nomura Global Markets Research, Nomura International (Hong Kong), 24 September.

Zhang, Z. and W. Chen (2013), "China: Rising Risks of Financial Crisis", Asia Special Report, Nomura Global Economics, Nomura International (Hong Kong), 15 March.

Zhu, H. G. Ng, and L. Jiang (2013), "Economic Research Note: Shadow Banking in China", Economic Research Global Data Watch, J. P. Morgan Chase Bank Hong Kong, 3 May. 


\section{WORKING PAPERS}

The full series of Economics Department Working Papers can be consulted at www.oecd.org/eco/workingpapers

1115. Economic policies and microeconomic stability: a literature review and some empirics (April 2014) by Paula Garda and Volker Ziemann

1114. How to improve Israel's health-care system (April 2014) by Philip Hemmings

1113. How to improve taxes and transfers in Israel (April 2014) by Philip Hemmings

1112. New evidence on the determinants of industrial specialisation (April 2014) by Asa Johansson and Eduardo Olaberria

1111. Economic growth from the household perspective: GDP and income distribution developments across OECD countries

(April 2014) by Orsetta Causa, Sonia Araujo, Agnès Cavaciuti, Nicolas Ruiz and Zuzana Smidova

1110. Would a growth slowdown in emerging markets spill over to high-income countries? A quantitative assessment (April 2014) By Patrice Ollivaud, Elena Rusticelli and Cyrille Schwellnus

1109. Short-term indicator models for quarterly GDP growth in the BRIICS: A small-scale bridge model approach

(April 2014) by Thomas Chalaux and Cyrille Schwellnus

1108. The prudential regulation of financial institutions: why regulatory responses to the crisis might not prove sufficient

(March 2014) by William R. White

1107. OECD forecasts during and after the financial crisis: a post mortem

(March 2014) by Nigel Pain, Christine Lewis, Thai-Thanh Dang, Yosuke Jin and Pete Richardson

1106. Fairly sharing the social impact of the crisis in Greece

(January 2014) by Vassiliki Koutsogeorgopoulou, Manos Matsaganis, Chrysa Leventi and Jan-David Schneider

1105. Dividing the pie in Brazil: income distribution, social policies and the new middle class (January 2014) by Jens M. Arnold and João Jalles

1104. New indicators of competition law and policy in 2013 for OECD and non-OECD countries (December 2013) by Enrico Alemani, Caroline Klein, Isabell Koske, Cristiana Vitale and Isabelle Wanner

1103. The effect of government debt, external debt and their interaction on OECD interest rates (December 2013) by David Turner and Francesca Spinelli 
1102. The state of the banking sector in Europe

(December 2013) by Dirk Schoenmaker and Toon Peek

1101. Getting Irish youth on the job track

(December 2013) by Alberto González Pandiella

1100. New econometric estimates of long-term growth effects of different areas of public spending (December 2013) by Omar Barbiero and Boris Cournède

1099. Cross-country spillovers from fiscal consolidations

(December 2013) by Antoine Goujard

1098. Informal employment in Russia: definitions, incidence, determinants and labour market segmentation

(December 2013) by Hartmut Lehmann and Anzelika Zaiceva

1097. Capacity needs in the automobile industry in the short- to medium run

(November 2013) by Caroline Klein and Isabell Koske

1096. Environmental policies and productivity growth - a critical review of empirical findings

(November 2013) by Tomasz Koźluk and Vera Zipperer

1095. Green growth challenges and the need for an energy reform in Mexico

(November 2013) by Carla Valdivia de Richter

1094. From bricks to brains: increasing the contribution of knowledge-based capital to growth in

Ireland

(November 2013) by David Haugh

1093. China's march to prosperity: reforms to avoid the middle-income trap

(November 2013) by Vincent Koen, Richard Herd and Sam Hill

1092. Multi factor productivity with natural capital

(November 2013) by Nicola Brandt, Paul Schreyer and Vera Zipperer

1091. Growth-promoting policies and macroeconomic stability

(November 2013) by Douglas Sutherland and Peter Hoeller

1090. Policies for inclusive urbanisation in China

(October 2013) by Vincent Koen, Richard Herd, Xiao Wang and Thomas Chalaux

1089. Fiscal devaluation - can it help to boost competitiveness?

(October 2013) by Isabell Koske

1088. How to achieve growth- and equity-friendly fiscal consolidation? A proposed methodology for instrument choice with an illustrative application to OECD countries

(October 2013) by Boris Cournède, Antoine Goujard and Álvaro Pina

1087. Improving school-to-work transition in New Zealand

(September 2013) by Alexandra Bibbee 